bioRxiv preprint doi: https//doi.org/10.1101/2022.02 27.481874· this version posted March 1 2022. The copyright holder for this preprint (which was not certified by peer review) is the author/funder, who has granted bioRxiv a license to display the preprint in perpetuity. It is made available under aCC-BY-NC-ND 4.0 International license.

\title{
Molsw2 activity could be the missing link between adaptation and mutation instrumental for natural adaptation-directed fast evolution (NADFE) of Magnaporthe oryzae.
}

\author{
Mengtian Pie ${ }^{1}$, Yakubu Saddeeq Abubakar ${ }^{2,3}$, Hina Ali ${ }^{1}$, Xianying Dou ${ }^{1}$, Guodong $\mathrm{Lu}^{1}$, Zonghua \\ Wang $^{1,4}, \mathrm{Ya} \mathrm{Li}^{1^{*}}$ Stefan Olsson ${ }^{1,5^{*}}$ \\ ${ }^{1}$ State Key Laboratory of Ecological Pest Control for Fujian and Taiwan Crops, College of Plant \\ Protection, Fujian Agriculture and Forestry University, Fuzhou 350002, China \\ ${ }^{2}$ Key Laboratory for Plant-microbe Interaction, College of Life Sciences, Fujian Agriculture and \\ Forestry University, Fuzhou 350002, China \\ ${ }^{3}$ Department of Biochemistry, Faculty of Life Sciences, Ahmadu Bello University, Zaria, Nigeria \\ ${ }^{4}$ Institute of Oceanography, Minjiang University, Fuzhou, China \\ ${ }^{5}$ Plant Immunity Center, Haixia Institute of Science and Technology, College of Life Science, Fujian \\ Agriculture and Forestry University, Fuzhou 350002, China \\ *Correspondence: \\ Ya Li and Stefan Olsson
}

liya-81@163.com \& Stefan@olssonstefan.com

\section{Abstract}

Isw2 is known to bind DNA, using a Myb-type DNA binding domain and with another part of the protein interact with histones in the closest nucleosome to pull the two closest nucleosomes closer to the binding site using ATP. These bindings hinder these nucleosomes' sliding movements and affect histone tail modification and DNA methylation but give more space for sliding and access for transcription factors further away from the Isw2 DNA binding sites. In a previous paper, we have knocked out the Magnaporthe oryzae Isw2 protein and complemented it with a GFP-labelled construct. We found that the MolSW2 is needed, especially in the later necrotrophic stages of infection when the plant starts defending itself.

Using published transcriptomic data, we have now found that MoISW2 is mainly co-regulated with Histone 4 (MoHIS4), which likely indicates that Molsw2 predominately interacts with MoHis4. We performed a ChIP-seq experiment using Molsw2-GFP to map the binding sites and investigated if Molsw2 regulates genes by the limited sliding type and if this regulation could be involved in pathogenicity regulation. Common motifs were found in the binding DNA sequences using MEME. Interestingly, these motifs were mainly intergenic, and a dominant palindrome motif was present in 200 sequences.

We further performed an RNAseq for $\triangle$ Moisw2 compared with Ku80 background strain and used genes sorted in physical order on the supercontigs to determine the effect of the mutation on the regulation of the genes physically close to the Molsw2 binding sites. The genes close to the binding site were more absolutely regulated in the $\Delta$ Moisw2 mutant. As nucleosomes are evenly distributed at roughly $200 \mathrm{bp}$ distance, there should be an interference pattern of regulation of genes centered around the Molsw2 DNA binding site if the genes are roughly evenly distributed, which could be confirmed. We queried the NCBI database again and checked where the 200 palindromic sequences were found in the genome to investigate if Molsw2 binds to any known structures in the DNA. The palindromic sequences were found in conserved retrotransposon elements that generally contain 
palindromes. Since these retrotransposon elements can move place, they can create new regulatory variations with Molsw2. Many avirulence genes recognized by different host plant cultivars and typically vary in expression between pathogen isolates were close to the Molsw2 DNA binding site. That could mean that mobile elements associated with some Molsw2 DNA binding sites are involved in creating variations in the pathogenicity of different $M$. oryzae strains. To test this idea, we searched through the transcriptomic data of our strain (70-15) and another strain (98-05) for variation in AVR expression during infection and if differences in Molsw2 binding could be the cause for this variation and it seems to be that. Finally, we found that most of the genes upregulated in the $\triangle$ Moisw2 mutant regulate biomass growth (DNA-binding and quality control and TFs overrepresented). In contrast, the ones downregulated have to do with mainly mitochondrial oxidative phosphorylation, oxidative stresses, and secondary metabolites. Similar results for enriched and depleted genes were found for all genes in our ChIP-seq data for genes closest to Molsw2 binding. We conclude that Molsw2 interaction with nucleosomes and binding to palindromic DNA in transposons located between genes creates a possibility for fast variation of offspring regulatory pattern without loss of genes through mutation and fast creation of M.oryzae strains with new cultivar host ranges in response to defenses by resistant cultivars and consequently a fast break of resistance. MoISW2 also seems to aid in the natural adaptation-directed fast evolution (NADFE) of M. oryzae, which is discussed as a new concept for Eukaryotes.

\section{Author contributions:}

Mengtian Pie: ChIPseq and initial analyses; RNAseq and initial analyses; manuscript preparation and writing.

Yakubu Saddeq Abubakar: Constructive manuscript critique; manuscript corrections

Hina Ali: ChPseq; RNAseq

Xianying Dou: Constructive manuscript critique; manuscript corrections

Guodong Lu: Supervision; manuscript corrections

Zonghua Wang: Supervision; manuscript corrections

Ya Li: Obtaining funds; supervision; initial planning of experiments; manuscript preparation and writing

Stefan Olsson: ChIPseq and RNAseq extended analyses and synthesis; MEME, FungiFun, antiSMASH analyses; manuscript planning; manuscript preparation and writing.

Keywords: heterochromatin, epigenetics, nucleosomes, avirulence genes, retrotransposons, evolution 


\section{Introduction}

The eukaryotic genome is organized into condensed nucleosomes limiting access to DNA for transcription factors and more loosely packed regions easier to access for interaction with DNA for transcription factors and repressors. The cell inheritance of this pattern is the basis of animal cell line specialization during embryogenesis (Serrano et al., 2013). Thus DNA accessibility also in fungi plays an essential role in determining which genes can be accessed to be efficiently transcribed (Huang et al., 2021).

ISW2 proteins contain a Myb/Sant domain close to their C-terminal that binds DNA. Isw2 has a histone binding domain that interacts with Histone 4 of a nucleosome and a catalytic ATPase domain that can react with ATP and change the protein (Whitehouse et al., 2007; Hota and Bartholomew, 2011; Dang et al., 2014) then the protein change conformation so that the nucleosome moves towards the DNA binding point of the ISW2 (Fazzio et al., 2005). Since this happens in both directions, it has been shown that it causes a localized nucleosome condensation (heterochromatin) that negatively affects the expression of the genes closest to the DNA-binding site (Whitehouse et al., 2007). There has been much research into this area, but it has become clear that in vitro mapping of ISW2 binding and nucleosome positioning does not reflect what happens in vivo (Fazzio et al., 2005; Donovan et al., 2021). In both these articles, the authors suggested that ISW2 is involved in targeted nucleosome positioning around their DNAbinding site based on their results. The nucleosomes closest to the ISW2 binding sites get locked by interacting with ISW2, whose activity keeps them close together while nucleosomes at a further distance get less condensed and nucleosomes more freedom to move. The accessibility for transcription will then be limited close to the ISW2 DNA binding site while varying with distance from it in a sinus wave pattern caused by the possibility for nucleosome movements (Donovan et al., 2021). Furthermore, ChIP seq experiments have shown that both the largest subunit of the ISW2 complex, ISW2, and Itc1, are needed for robust, target-specific binding to DNA while ISW2 is sufficient for basal level binding (Fazzio et al., 2005).

We have previously identified all Myb containing DNA binding proteins to investigate if any of them have a role in pathogenicity. We then found a MolSW2 candidate since it has an MYB/SANT domain (in our paper, the gene was named MoMyb15) that had considerable effects on the later necrotrophic stages of infection (Li et al., 2021). Especially interesting is if MolSW2 regulates pathogenicity-related genes at later stages of infection when the fungus is exposed to stresses imposed by the plant defenses and since the deletion of the gene significantly affected M. oryzae pathogenicity (Li et al., 2021).

We now find that the MoISW2 protein regulates gene expression consistent with regulation through epigenetics through DNA and nucleosome binding. The most upregulated genes by the MolsW2 activity are genes involved in mitochondrial, oxidative stress-related genes and the production of secondary metabolites. This activity is also likely to help create positive mutation bias, as very recently shown to exist for genes involved in reacting to the environment (Monroe et al., 2022) in genes affected by the MolSW2 activities. Most downregulated genes favor DNA synthesis, DNA quality control needed for fast DNA synthesis, and biomass growth. Our results indicate that MolSW2 also silences avirulence genes differently in different $M$. oryzae isolates. The MoISW2 binding is commonly in retrotransposon-like DNA sequences between genes, pointing to that MoISW2 binding sites and regulation can be shifted evolutionary quickly in the M. oryzae genome. 


\section{Results}

\section{Correlation analyses of ISW2 expression with expressions of nucleosomal histones}

Histone 1 is involved in epigenetic silencing, and its expression and density are linked to the silencing activity (Willcockson et al., 2021). Isw2 binds DNA and histone 4 (Donovan et al., 2021). To investigate correlations between histones and the putative Molsw2 for our strain, we used published expression data, from the course of infection, from many different published experiments, as we have done previously for other genes (Zhang et al., 2019) (70-15). The MoHIS1 expression increases steeply with MoISW2 gene expression. The putative MoISW2 is also found to be coregulated with a putative MoHIS4 in the downloaded data (Fig. 1). Thus, it could mean that the putative MolSW2 (Li et al., 2021) is a true MoISW2. The expression of MoHIS2B is related to the overall growth rate (Zhang et al., 2019) and is correlated with MolSW2, but not with a steep slope, indicating that a smaller amount of MoHis2B is needed for the DNA synthesis per cell. Similarly, for the expression of MoHIS3 but not for MoHIS2A, that are not significantly correlated with the putative MoISW2. (Fig. S1). The other histones expressions were less correlated with the putative MoISW2 (Fig. S1). Isw2 works togeter with ITC1 and His4 thus the expression of these three putative genes should be correlate in $M$. oryzae, and they are nicely correlated in the data from plant infection (Fig. S2).

A

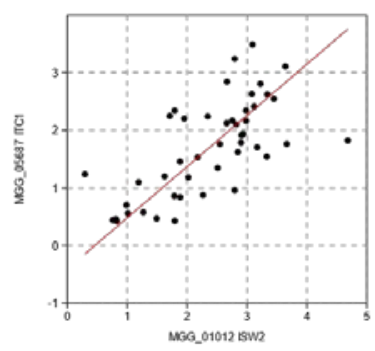

C

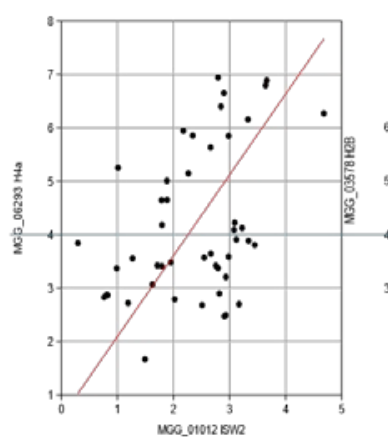

D
B

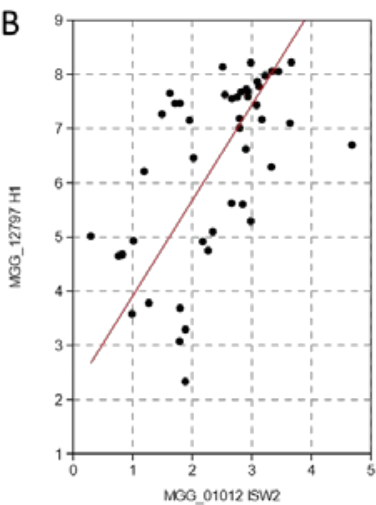

E

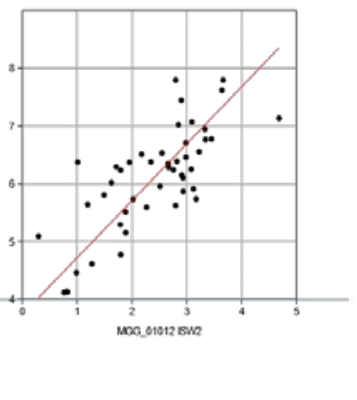


Figure 1. Log2 correlations of a putative ITC1, the linker histone Histone1 and the two putative histone 4 genes known to interact, with the expression of the putative MolSW2 (x-axis) in published RNAseq data at different stages of plant infection. Each dot corresponds to the value from one transcriptome. (A) ITC1, $\mathrm{P}$ (uncorr) $=1.57 \mathrm{E}-7$ (B) Histone $1, \mathrm{P}$ (uncorr) $=1.48 \mathrm{E}-5$ (C) Histone 4a $\mathrm{P}$ (uncorr) $=0.0044$ (D) Histone 4b $P$ (uncorr) $=3.81 E-7$ (E) Histone $4 a+4 b$ since both Histone 4 genes are predicted to encode for exactly the same protein, $\mathrm{P}$ (uncorr) 5.82e-10. All plots are shown with equal $\mathrm{x}$ and $\mathrm{y}$ scale gradings so that it is easy to compare slopes between graphs visually. Also, note that figures C, D, E have been positioned so that Log 4 on the $Y$-axes are on the same line so that the effect of the addition, Log2(His4a+His4b), can be seen visually.
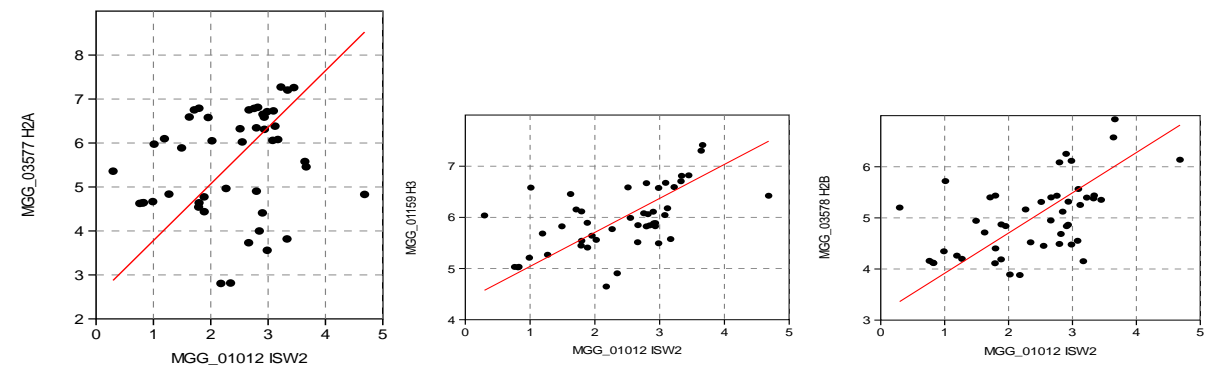

Figure S1. Log2 correlations of a putative MoHIS2a, MoHIS3 and MoHIS2B with expression of MolSW2 (xaxis) in published RNAseq data at different stages of plant infection. (A) MoHIS2a, P(uncorr $=0.20$ (B) MoHIS3, $\mathrm{P}$ (uncorr) $=8.94 \mathrm{E}-5$ (C) MoHIS2B, $\mathrm{P}$ (uncorr) $=3.56 \mathrm{E}-5$.

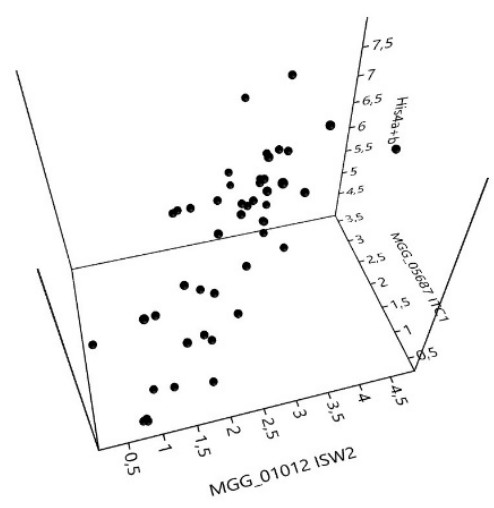

Figure S2. 3D plot showing Log of expression of MolSW2, MolTC1, and MoHIS4a+b that, according to the literature, need to work together to influence nucleosome packing.

Thus, the putative MolSW2 gene likely encodes a putative Molsw2 protein involved in targeted local chromatin compaction working with MoHis1 and MoHis4 (Fazzio et al., 2005; Donovan et al., 2021; Willcockson et al., 2021). From now on, we skip "putative" as an attribute and investigate if Molsw2 has the expected functions as an Isw2 and what other effects it likely has on the biology of the fungus. Also, the local chromatin compaction caused by Molsw2 should be dynamic and more decisive the more the gene and the protein are expressed.

\section{ChIP-seq analysis to find likely intergenetic palindromic DNA binding motifs}

We used a MolSW2-GFP construct from our previous study (Li et al., 2021) to perform a ChIP-seq analysis to find conserved DNA binding motifs for the binding of Molsw2 to M. oryzae DNA sequences. We looked especially for palindromic motifs in the sequences interacting with Molsw2- 
GFP since our hits in the ChIP-seq data showed hits mainly for intergenic sequences (Supplemental Data 1), where transposable elements (TEs) are commonly located with TE target sites that are often palindromic (Linheiro and Bergman, 2008). In addition, TEs are involved in stress adaptation, and host specialization of M. oryzae (Chadha and Sharma, 2014; Yoshida et al., 2016), and our previous work showed Molsw2 to be especially needed when plant host innate immune responses are known to be high (Li et al., 2021). In addition, interacting with a palindromic sequence that is also likely to form hairpin structures in DNA (Ganapathiraju et al., 2020) can make "non-sliding" anchors for Molsw2 to pull nucleosomes closer. We found the most common palindromic motif in 196 of our ChIP-seq DNA sequences using the MEME website, and there, the MEME search engine to search for common motifs (Fig. 2A. Supplemental Data 2). This motif has similarities with a staggered-cut palindromic target site involved in transposon cut and paste (Linheiro and Bergman, 2008).

Using a TOMTOM search at the MEME website, we could see that the found palindromic motif has similarities to a known Myb-binding protein containing DNA binding motif from humans (Fig. 2B Supplemental Data 3). The large number of palindromic hits and their alleged similarities with a human Myb since ISW2 contains a Myb-SANT domain (Li et al., 2021) made us focus on these 196 hits to investigate how and if genes are regulated around these sites in the genome to test if MolSW2 is involved in local chromatin compaction around the sites of these palindromic DNA motifs for MolSW2 DNA binding.
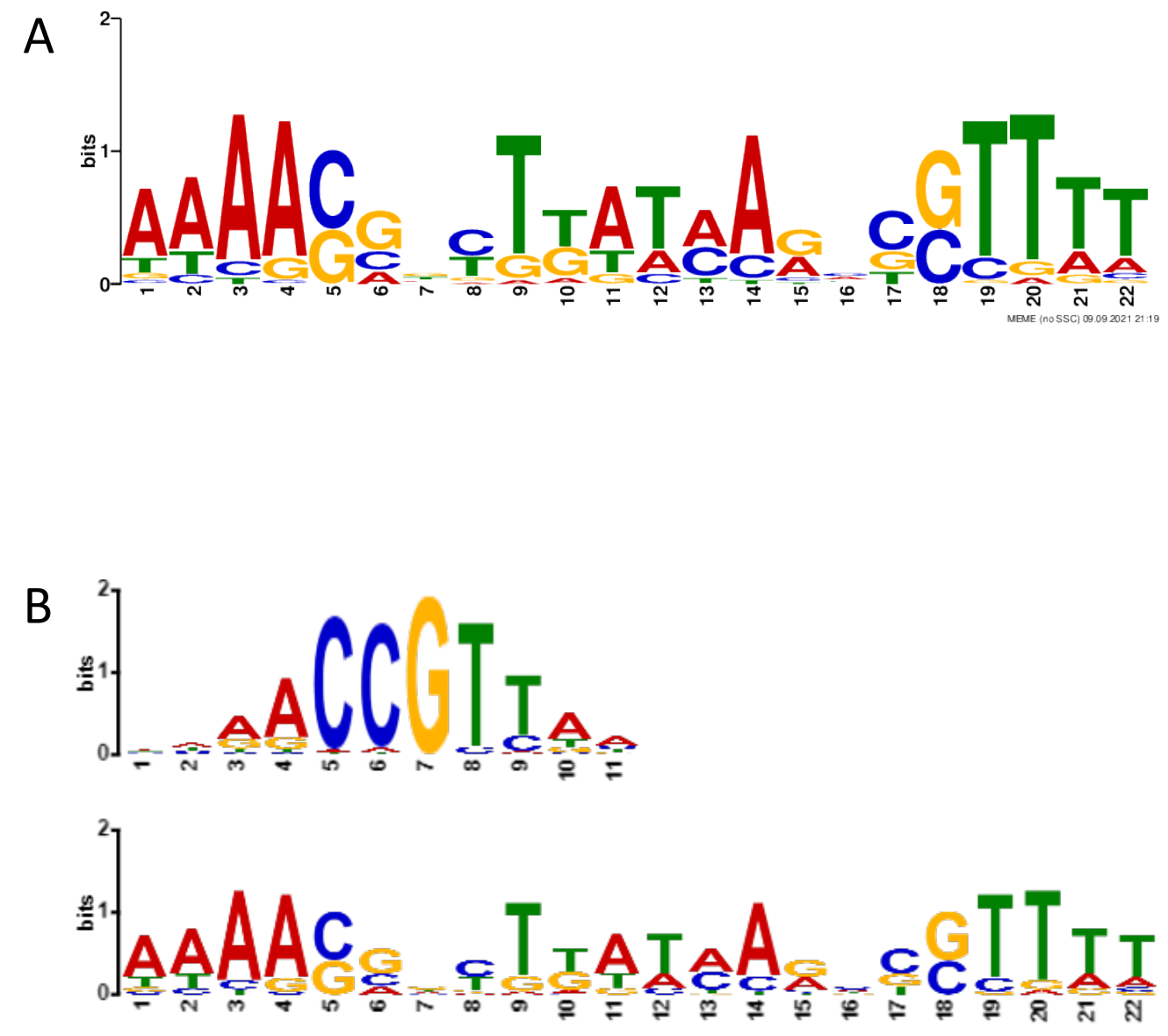
bioRxiv preprint doi: https//doi.org/10.1101/2022.02.27.481874 this version posted March 1, 2022. The copyright holder for this preprint (which was not certified by peer review) is the author/funder, who has granted bioRxiv a license to display the preprint in perpetuity. It is made available under aCC-BY-NC-ND 4.0 International license.

Figure 2. One common palindromic motif was found for Molsw2 DNA binding in M.oryzae gene promoter regions. (A) The motif is found in 196 ChIP-seq sequences. (B) Comparison of the motif (Top) with the known human Myb protein DNA binding motif (bottom) found by TOMTOM. The ISW2 DNA binding domain is a Myb/SANT domain.

\section{The binding of Molsw2 regulates the genes closest to the motif binding site}

We found that the196 motifs for binding sites were primarily intergenic, and we investigated the regulation of the genes closest to these 196 Molsw2 binding sites to see if Molsw2 restricts the regulation of the genes closest to the DNA binding site, as would be expected (Donovan et al., 2021). We searched all ChIP-seq sequences against the NCBI database and found good hits for 176 of the 196 motifs. Most of these hits were intergenic (113), while the rest (63) were in the promoter region. We next performed an RNAseq for the $\triangle M$ Moisw2 strain and the background Ku80 strain, where we investigated the regulation of the gene with the hit in the promoter region or the closest gene to the intergenic binding site (Fig. 3). Only genes expressed at all in our datasets were included in the analysis. There was a general upregulation of the closest genes to the Molsw2 binding site in the $\triangle$ Moisw2 mutant (Fig. 3A). For these genes, the $\triangle$ Moisw2 / Ku 80 expression ratio is lower when the Molsw2 is predicted to bind directly in the promoter region than for the closest gene of a predicted intergenic binding. When the absolute (positive or negative) regulation was considered, on the other hand, both types of genes with Molsw2 binding in the promoter had similar absolute regulation indicating that many genes with Molsw2 binding their promoter region are repressed in $\triangle$ Moisw2 (Fig. 3B). The latter supports Molsw2 as an Isw2 protein that creates a local nucleosome condensation at specific nucleosomes (Donovan et al., 2021).
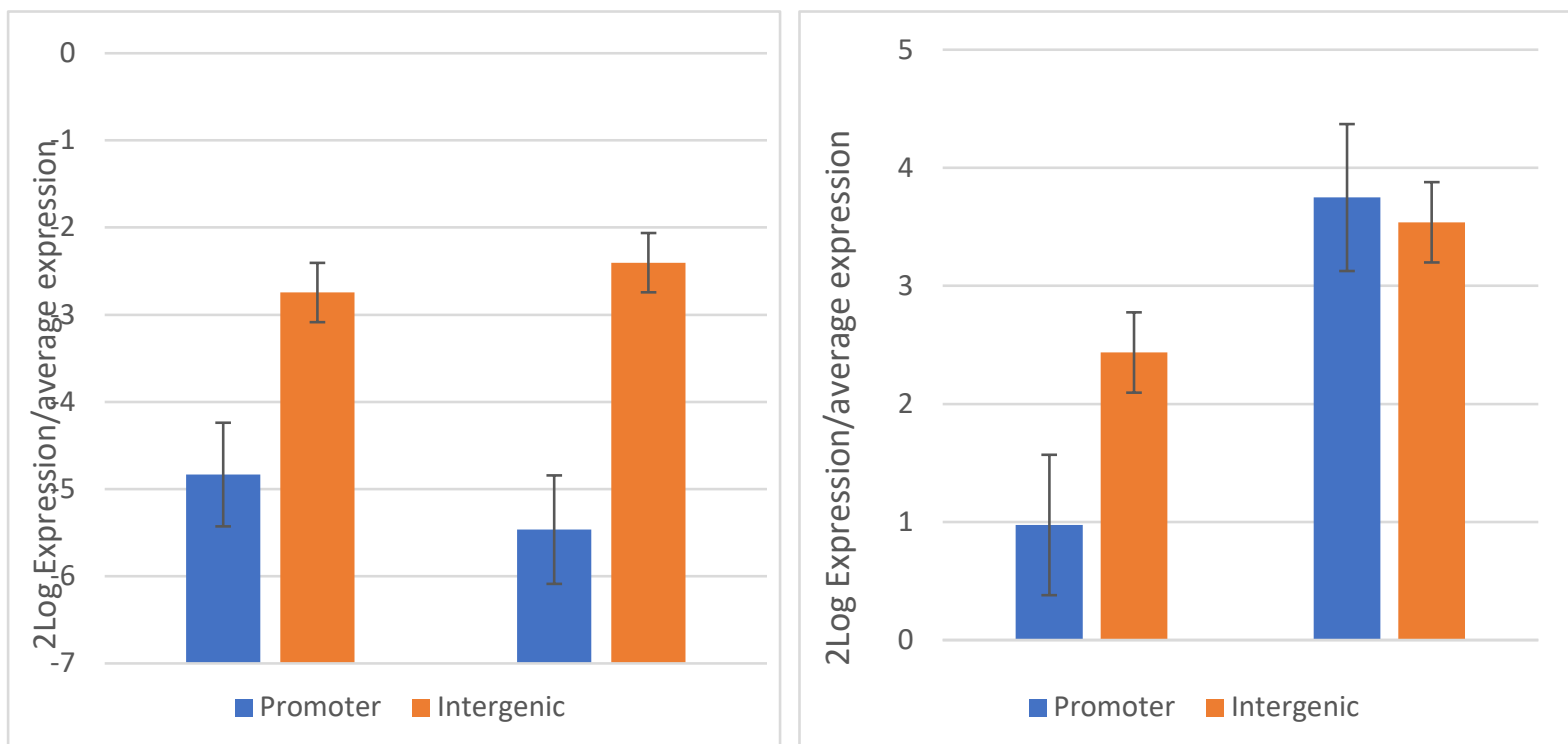

Figure 3. Regulation of genes closest to the predicted palindromic Molsw2 binding site with hits for the MolSW2 binding in the ChIP-seq data. (A) Expression was on average higher in $\Delta M o i s w 2$ than $K u 80$ of genes closest to the binding site or with the motif in their promoter region. (B) Change in expression for genes with a binding site in the promoter region and the closest gene when ISW2 is intergenic. Deleting MolSW2 upregulates both types of genes and upregulates genes more slightly further away from the binding site while the absolute (plus or minus) regulation is equal for both types of genes (816 times regulation). Error bars indicate SEM (Promoter $\mathrm{N}=63$ Intergenic $\mathrm{N}=112$ ).

Several genes close to the Molsw2 binding site were neither expressed in 4 Moisw2 nor Ku80, indicating that these genes could be permanently non-expressible potential pseudogenes without 
biological roles. We only use the term pseudogene in its limited sense (Cheetham et al., 2020) for genes that look like genes without any roles and are not expressed under many natural conditions. Since the overuse of the pseudogene term does not make sense, we follow the nomenclature suggested (Cheetham et al., 2020). Since the non-existence of a role can never be firmly tested experimentally, we prefer to call it a potential pseudogene. Our observation that these genes are or have become potential pseudogenes during evolution is exciting since some genes are annotated as avirulence genes (see Table 1). The data and analyses for this and the next section is available in a supplemental file (Supplemental Data 4)

\section{Local gene regulations around Molsw2 palindromic DNA binding sites fit the Isw2 specific DNA binding model and can likely be used to estimate the NRL size around the binding site.}

To further investigate local regulation around the binding sites with the found palindromic motif, we investigated our RNAseq data and ordered the MGG_codes for the genes in the order of the genes on the supercontigs (Supercontig order downloaded from BROAD). We found that genes upstream and downstream, the genes closest to the binding site ( $+8 /-8$ genes), were generally differently regulated, and $\triangle M$ Moisw2 differed from the background $K u 80$ in this respect.

Because of the targeted local nucleosome condensation, the gene regulation around the Isw2 binding site (Donovan et al., 2021) $\triangle M$ Moisw2/W.T. regulation should be in waves around the DNA attachment point due to the likely interference pattern (phasing) between nucleosome repeat lengths (NRLs) and the average distance between gene promoter sequences, if the average gene distance is similar for most genes (Chereji et al., 2018). We first calculated the average gene distance in M.oryzae using the downloaded data from BROAD and found that the average distance is $4659 \mathrm{bp}$ for all genes ordered on supercontigs with a relatively small standard error of $203 \mathrm{bp}$ (SEM=4\%). We then searched for the best fit of a sinus function of the $\Delta M$ Misw2/Ku80 transcription using our gene expression data (RNAseq) of the $+8 /-8$ genes surrounding the Molsw2 binding site. We used MS Excel Solver to fit a reflecting sinus wave, reflecting with a minimum in the Molsw2 attachment point. We used a sinus function since DNA are wrapped around and slides around nucleosomes of similar sizes, with a constant overall NRL (van Holde, 1989; Cutter and Hayes, 2015; Donovan et al., 2021; Willcockson et al., 2021) and NRLs sizes depending on the organism, cell type and cell status (van Holde, 1989). We found a general up-regulation at the point of DNA-interaction (Fig. 3) and waves of regulation on each side of the DNA-binding site for Molsw2 probably due to changed nucleosome phasing affecting the in vivo transcription (Chereji et al., 2018) differently in $\Delta M o i s w 2$ and the background Ku80. By searching for the best fit with the minimum wavelength (Fig. 4) that can create the observed data, we could approximate that the predicted average NRLs close to the Molsw2 DNA attachment should be $211 \mathrm{bp}$ with an SEM of 9bp. That roughly agrees with Donovan et al. (2021) and what could be expected for not highly condensed NRLs (van Holde, 1989).

Since Isw2 interacts with histone 4 (Donovan et al., 2021), we made a few attempts to detect Molsw2 interaction with a putative MoHis4 protein using a yeast two-hybrid assay. We could not detect any interaction solid and long enough to give a positive result. Thus, there might be no interaction, or the interaction is very transient; the latter is likely (see discussion). 
bioRxiv preprint doi: https://doi.org/10.1101/2022.02.27.481874; this version posted March 1, 2022. The copyright holder for this preprint (which was not certified by peer review) is the author/funder, who has granted bioRxiv a license to display the preprint in perpetuity. It is made available under aCC-BY-NC-ND 4.0 International license.

A

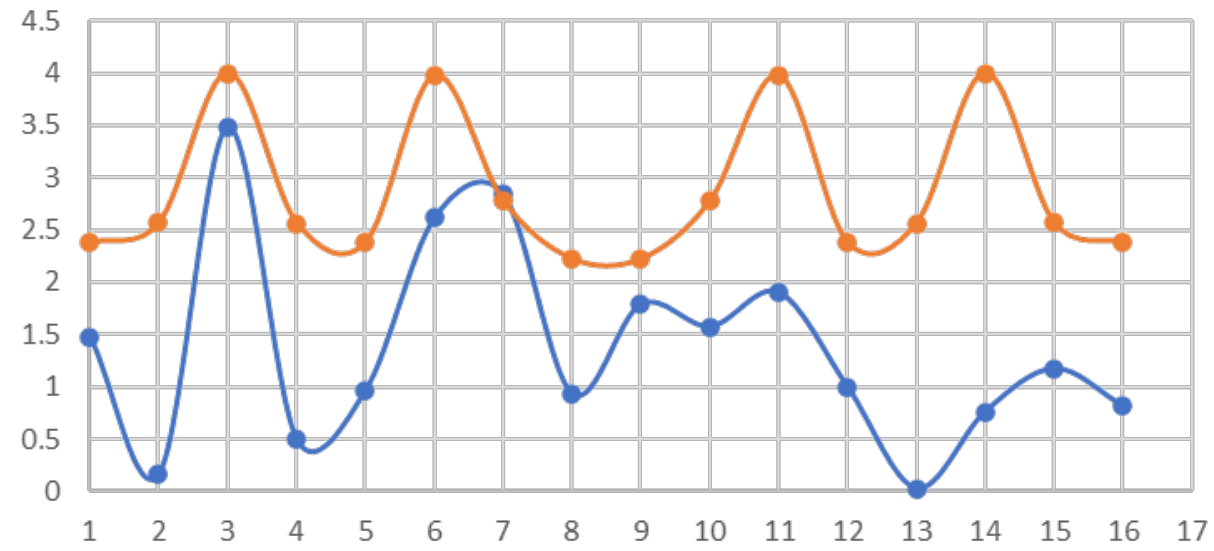

B

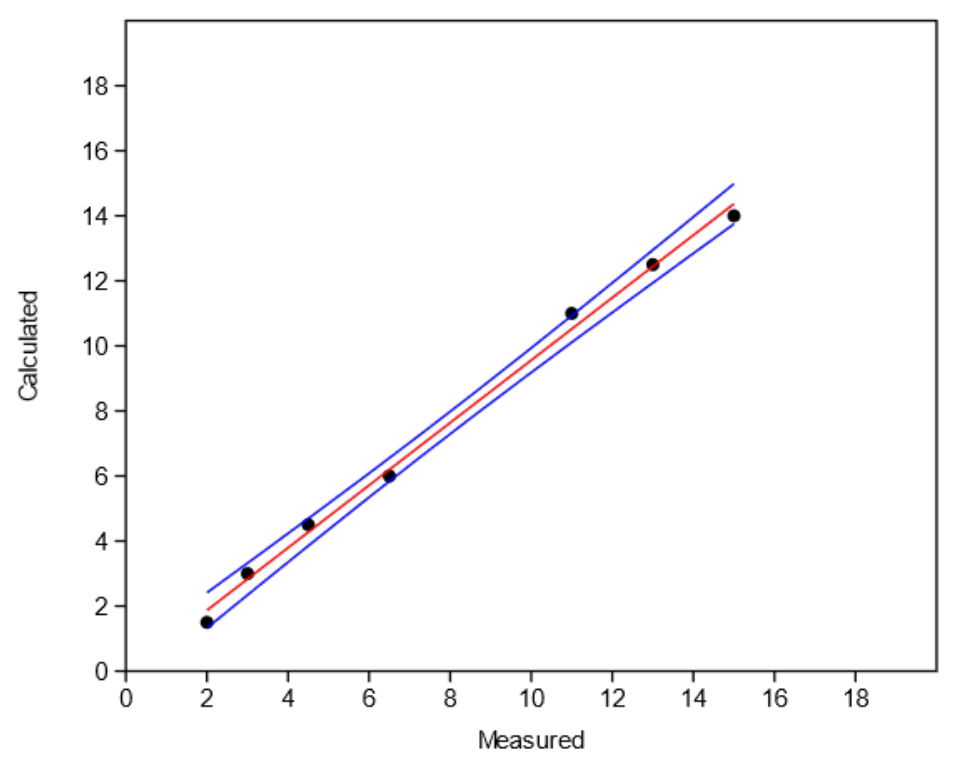

Figure 4. $2 \log \Delta$ Moisw2 mutant/Ku80 expression of the genes -8 to +8 genes around the palindromic Molsw2 palindromic binding site (8.5) occurs in waves. (A) Fitting a sinus curve with reflection at the Molsw2 binding sites. (B). The linear regression correlates between peak and valley positions read from the two graphs in the top figure, showing that the curves are well in phase with each other. Black =Peak position Red=valley position. Blue lines (95\% confidence interval for the relationship). 
bioRxiv preprint doi: https//doi.org/10.1101/2022.02 27.481874 this version posted March 1, 2022. The copyright holder for this preprint (which was not certified by peer review) is the author/funder, who has granted bioRxiv a license to display the preprint in perpetuity. It is made available under aCC-BY-NC-ND 4.0 International license.

\section{Palindromic sequences between genes often target transposon sequences, and MoISW2 DNA binding the palindromic DNA motif can influence close-by avirulence genes expression.}

Palindromic DNA are typical mobile elements of retrotransposons. Most of the $196 \mathrm{ChIP}$-seq sequences with palindromic binding motifs are found in known mobile elements (transposons). Many transposons are described for the strain we worked with, so it was possible to find the blast position for the ChIP-seq sequences close to known transposon sequences between genes (data not shown). Avirulence proteins are pathogenicity-related fungal proteins that the plant senses and mounts innate immunity reactions towards. These genes are generally situated close to known retrotransposons in the M. oryzae genome (Yoshida et al., 2016).

Sub-hypothesis from the above observation: If avirulence gene expressions in $M$. oryzae are affected by MolSW2 targeted nucleosome condensation, then transposable elements interacting with Molsw2 could be directly involved in the pathogen-plant arms race between pathogen pathogenicity and plant resistance. Moreover, these genes should be adjacent to the Molsw2 binding site, and their expression should be affected differently depending on their closeness to the binding site.

To test this hypothesis, we first made a list of all known avirulence genes noted for $M$. oryzae at NCBI (Table 1). We found 16 avirulence genes of different types and the avirulence cluster for cytochalasan type compound biosynthesis (Collemare et al., 2008; Song et al., 2015) containing 12 more genes. The cytochalasan cluster is specifically activated at early hours post infection HPI during penetration and produces a secondary metabolite recognized by the $R$ gene Pi33 in resistant rice cultivars (Collemare et al., 2008). Avr-PWL1 and Avr-PWL2 (Dioh et al., 2000), together with the previous, makes 18 classic avirulence type genes excluding the cytochalasan gene cluster genes (Table 1).

Most of the genes in the cytochalasan cluster are very close to the Molsw2 palindromic DNA binding motif site, and several are differently expressed in 70-15 and 98-06 (Table 1), which might lead to the production of different final metabolites from the gene cluster even if the metabolites have similar functions as virulence factors.

Six of the other avirulence genes are not expressed in either strain (Table 1). Of these 6, half of the genes are close to the Molsw2 binding site, and 3 are further away in 70-15. Two Avir genes (MGG_17614 and MGG_15611) are on supercontigs with unknown gene-order in our data, so it is unsure how far they are from a Molsw2 binding site. The positioning of the Molsw2 binding site close to retrotransposons and the differential regulation and expression variation make it likely that Molsw2 specific targeting nucleosome binding is instrumental for stabilizing avirulence gene expression appropriately, concerning fungal-experienced plant host immune reactions. The data and analyses for this section is available in a supplemental file (Supplemental Data 5) 
bioRxiv preprint doi: https://doi.org/10.1101/2022.02.27.481874; this version posted March $1,2022$. The copyright holder for this preprint (which was not certified by peer review) is the author/funder, who has granted bioRxiv a license to display the preprint in perpetuity. It is made available under aCC-BY-NC-ND 4.0 International license.

Table 1. Comparison of the position of avirulence genes in relation to the Molsw2 palindromic DNA binding motif site in strain 70-15, as well as expression of the avirulence genes in MolSW2 knockout compared to the background; and expression of the same genes during infection of rice for strain 70-15 and strain 98-0 from published data. Yellow-marked cells; are genes that Molsw2 downregulates in 70-15. Orange marked cells; genes with no expression could be potential pseudogenes in 70-15 and/or 98-0. Green marked cells; are genes that are only expressed during infection by one of the strains

\begin{tabular}{|l|l|l|l|l|l|l|l|l|l|}
\hline ID. & Annotation & $\begin{array}{l}\text { Within or } \\
\text { outside } \\
\text { the+8/-8 } \\
\text { genes } \\
\text { around the } \\
\text { MoIsw2 } \\
\text { binding } \\
\text { site }\end{array}$ & $\begin{array}{l}\text { More } \\
\text { In KO } \\
(\mathrm{X})\end{array}$ & $\begin{array}{l}\text { Absent } \\
\text { express } \\
\text { ion in } \\
\text { both } \\
\text { strains } \\
(\mathrm{X})\end{array}$ & $\begin{array}{l}\text { Less } \\
\text { in } \\
\text { KO. } \\
(\mathrm{X})\end{array}$ & $\begin{array}{l}\text { Only } \\
\text { in 70- } \\
15 \\
(\mathrm{X})\end{array}$ & $\begin{array}{l}\text { Only in } \\
98-0 \\
(\mathrm{X})\end{array}$ & $\begin{array}{l}\text { Expressed } \\
\text { in both } \\
\text { strains and } \\
\text { in 70-15 } \\
\text { infection } \\
\text { data }\end{array}$ & $\begin{array}{l}\text { Expression } \\
\text { in WT 70-15 } \\
\text { infection } \\
\text { data }\end{array}$ \\
\hline MGG_12447 & cytochalasan & Within & $\mathrm{X}$ & & & & & $\mathrm{X}$ & $\mathrm{X}$ \\
\hline MGG_08386 & cytochalasan & Within & & $\mathrm{X}$ & & & & & $\mathrm{X}$ \\
\hline MGG_08377 & cytochalasan & Within & $\mathrm{X}$ & & & & & $\mathrm{X}$ & $\mathrm{X}$ \\
\hline MGG_08378 & cytochalasan & Within & $\mathrm{X}$ & & & & & $\mathrm{X}$ & \\
\hline MGG_08380 & cytochalasan & Within & & & & & $\mathrm{X}$ & & $\mathrm{X}$ \\
\hline MGG_08381 & cytochalasan & Within & & & & & $\mathrm{X}$ & & $\mathrm{X}$ \\
\hline MGG_08384 & cytochalasan & Within & $\mathrm{X}$ & & & & & $\mathrm{X}$ & $\mathrm{X}$ \\
\hline MGG_08389 & cytochalasan & Within & & & $\mathrm{X}$ & & & $\mathrm{X}$ & $\mathrm{X}$ \\
\hline MGG_08390 & cytochalasan & Within & & & & & & & $\mathrm{X}$ \\
\hline MGG_08391 & cytochalasan & Within & & & & & $\mathrm{X}$ & & $\mathrm{X}$ \\
\hline MGG_15927 & cytochalasan & Within & & & & & $\mathrm{X}$ & & \\
\hline MGG_15928 & cytochalasan & Within & $\mathrm{X}$ & & & $\mathrm{X}$ & & & \\
\hline
\end{tabular}

\begin{tabular}{|c|c|c|c|c|c|c|c|c|c|}
\hline & $\begin{array}{l}\text { Avirulence } \\
\text { genes }\end{array}$ & & & & & & & & \\
\hline MGG_07199 & $\begin{array}{l}\text { ATR13, RxLR } \\
\text { effector }\end{array}$ & Outside & & & & & & $\mathrm{X}$ & $X$ \\
\hline MGG_10556 & Avr_Pii & $\begin{array}{l}4 \text { genes } \\
\text { away }\end{array}$ & & $x$ & & & & & \\
\hline MGG_17614 & Avr_Pii & $\begin{array}{l}\text { nonorder } \\
\text { ed }\end{array}$ & & & $x$ & $x$ & & & ND \\
\hline MGG_13283 & Avr_Pik & Outside & & $x$ & & & & & \\
\hline MGG_15972 & Avr_Pik & $\begin{array}{l}\text { nonorder } \\
\text { ed }\end{array}$ & $x$ & & & & & $x$ & $X$ \\
\hline MGG_03029 & Avr_Pita1 & Outside & & & $\mathrm{X}$ & & & $x$ & $\mathrm{X}$ \\
\hline MGG_07038 & Avr_Pita1 & Outside & & & $x$ & & & $x$ & $x$ \\
\hline MGG_09617 & Avr_Pita1 & $\begin{array}{c}1 \text { genes } \\
\text { away }\end{array}$ & & $x$ & & & & & \\
\hline MGG_10927 & Avr_Pita1 & $\begin{array}{c}13 \text { genes } \\
\text { away }\end{array}$ & $x$ & & & & & $x$ & $X$ \\
\hline MGG_03808 & Avr_Pita1 like & Outside & & $x$ & & & & & \\
\hline MGG_15370 & Avr_Pita1 like & $\begin{array}{l}\text { 1genes } \\
\text { away }\end{array}$ & $\mathrm{X}$ & & & & & $x$ & $X$ \\
\hline MGG_17611 & $\begin{array}{c}\text { Avr_Pita1 } \\
\text { middle }\end{array}$ & $\begin{array}{c}\text { nonorder } \\
\text { ed }\end{array}$ & $x$ & & & & & & ND \\
\hline MGG_14981 & AVR_PiTA2 & Outside & & $x$ & & & & & \\
\hline MGG_15212 & AVR_Pita2 & $\begin{array}{l}\text { genes } \\
\text { away }\end{array}$ & & & & & $x$ & & \\
\hline MGG_18041 & Avr_Piz-t & $\begin{array}{c}\text { nonorder } \\
\text { ed }\end{array}$ & & & & & & $X$ & ND \\
\hline MGG_03685 & Avr-Pi54 & Outside & $x$ & & & & & $x$ & $x$ \\
\hline MGG_13863 & Avr-PWL1 & $\begin{array}{l}\text { 2genes } \\
\text { away }\end{array}$ & & & & & $x$ & & \\
\hline MGG_07398 & Avr-PWL2 & Outside & & & & $x$ & & & \\
\hline
\end{tabular}


bioRxiv preprint doi: https://doi org/10.1101/2022 .02 27.481874. this version posted March 1, 2022. The copyright holder for this preprint (which was not certified by peer review) is the author/funder, who has granted bioRxiv a license to display the preprint in perpetuity. It is made available under aCC-BY-NC-ND 4.0 International license.

\section{RNA-seq data of $\triangle M$ Moisw2 and Ku80 indicates that Molsw2 regulates the balance between glycolytic growth and biosynthesis and aerobic catabolism}

For $\Delta$ Moisw2 grown on MM-medium, 339 genes were significantly upregulated compared to the background Ku80. The two largest significantly overrepresented gene categories were for secondary metabolism and DNA-binding, while most of the other categories are related to DNA synthesis and DNA-related activities (Fig. 5A). These are the genes MolSW2 likely negatively regulates in Ku80. Most of the downregulated genes in the 4 Moisw2 are genes involved in mitochondrial electron transport and other mitochondrial processes. In other words, our results indicate that Molsw2 is involved in regulating the balance between DNA synthesis, which is safest without ATP generation by mitochondrial respiration that generates Radical Oxygen Species (ROS) (Klevecz et al., 2004).

A

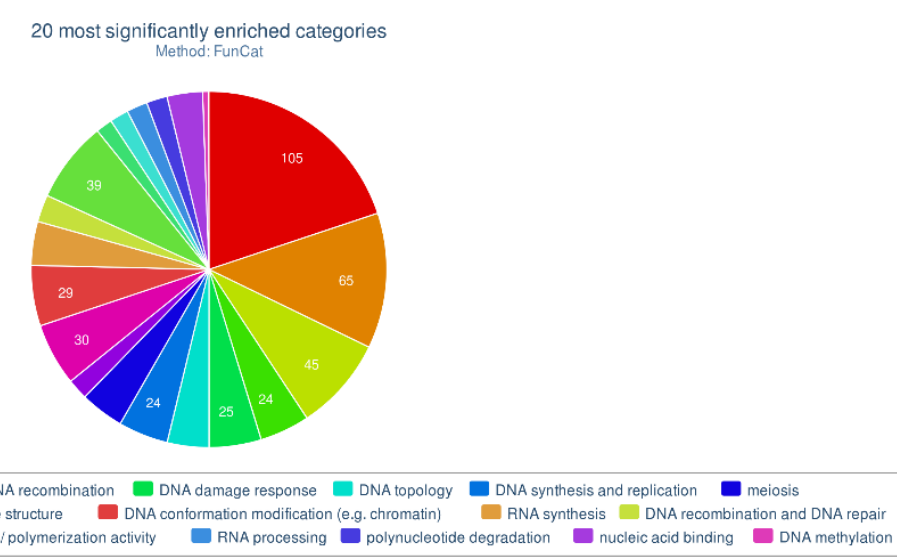

B

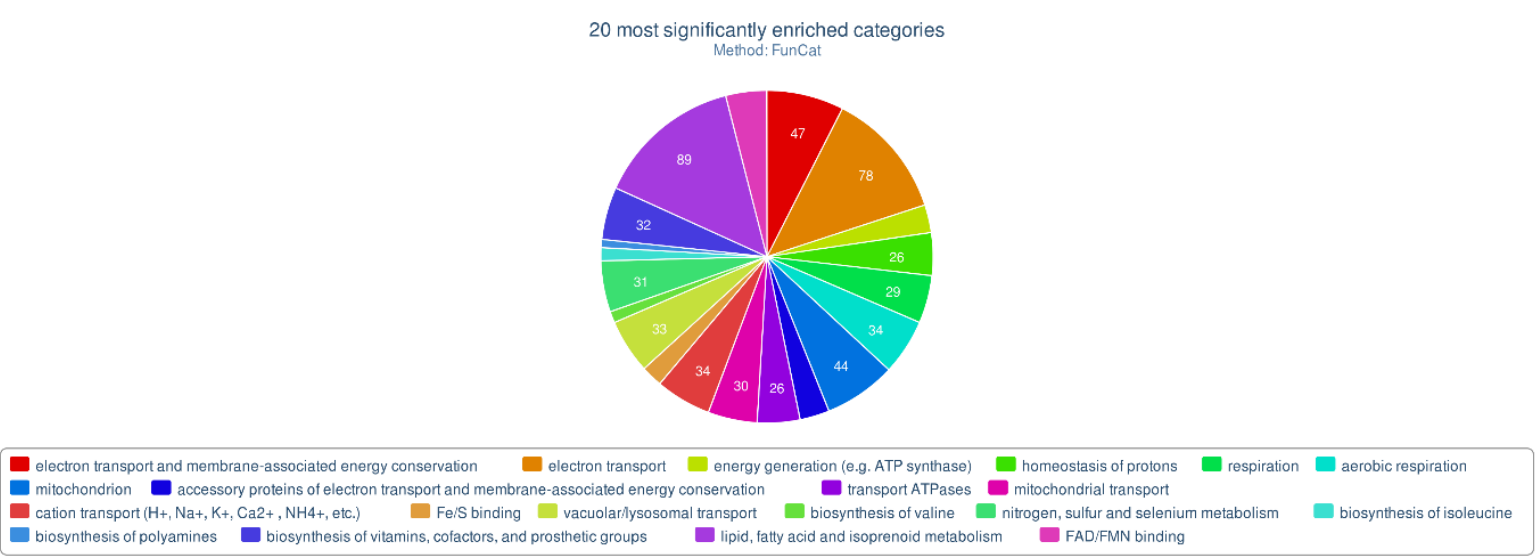

Figure 5. Differentially regulated FunCat gene categories in the $\triangle$ Moisw2 compared to the background strain Ku80. (A) Enriched upregulated genes in the mutant; Secondary metabolism, DNA-binding, and genes for DNArelated activities and synthesis (growth). (B) Enriched downregulated genes in the mutant; Mitochondrial activities like electron transport and mitochondrial biosynthesis.

\section{Regulation of DNA-binding genes closest to the Molsw2 binding site}

Since 65 genes above were classified as DNA-binding and were among the enriched genes upregulated in $\triangle M$ Moisw2 (Fig. 5A), we counted the number of genes positioned between these genes and the Molsw2 binding sites for all the DNA-binding genes. The products of 
bioRxiv preprint doi: https://doi.org/10.1101/2022.02 27.481874. this version posted March 1, 2022. The copyright holder for this preprint (which was not certified by peer review) is the author/funder, who has granted bioRxiv a license to display the preprint in perpetuity. It is made available under aCC-BY-NC-ND 4.0 International license.

some of these genes could be transcription factors directly under the control of MolSW2. We found that the most upregulated DNA binding genes in the $\triangle M o i s w 2$ are physically closest to the Molsw2 palindromic DNA binding motif site, indicating that deleting MolSW2 gives better DNA access for the promoters of DNA-binding genes situated close to the Molsw2 palindromic DNA binding motif site (Fig. 6).

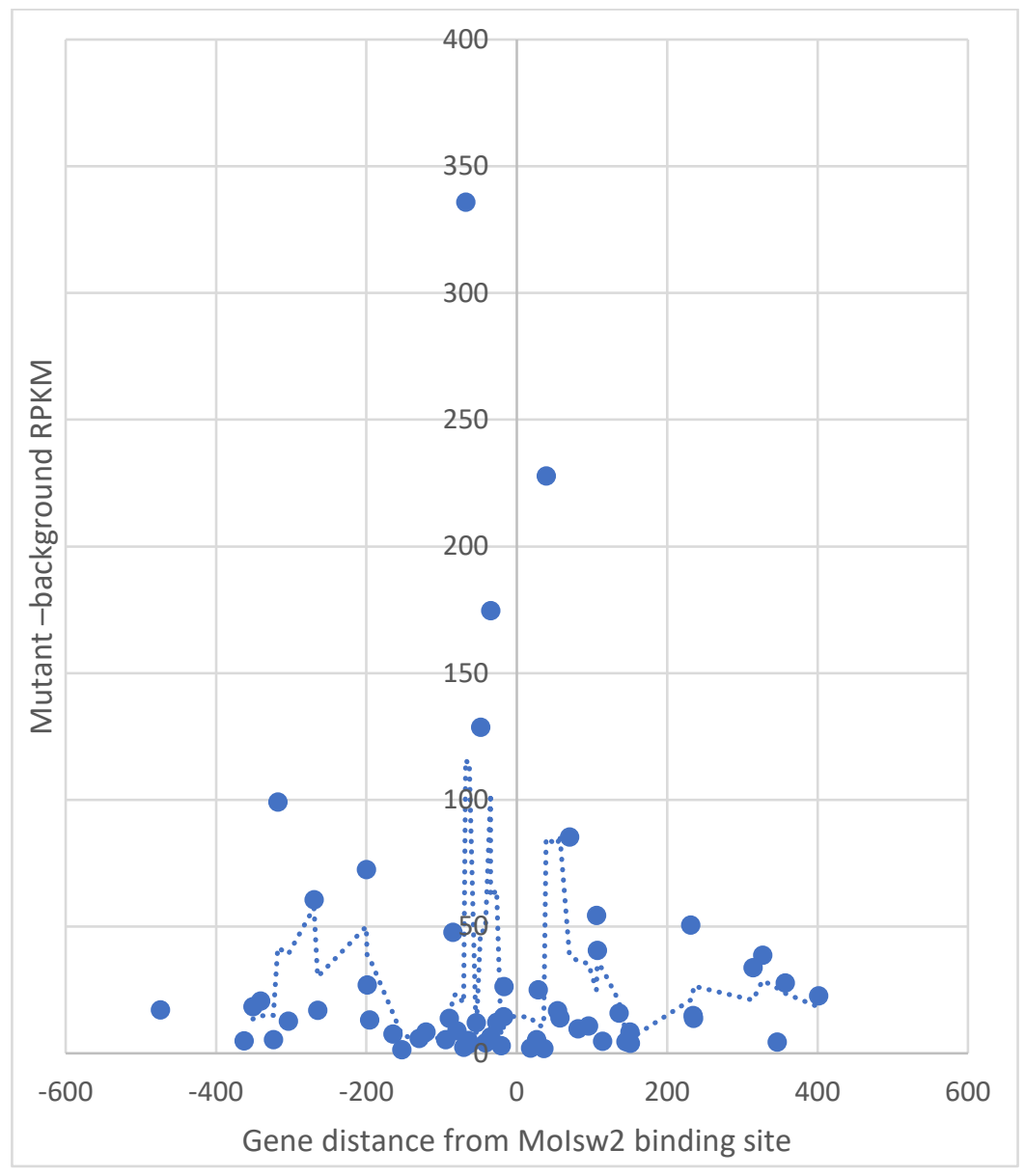

Figure 6. The enriched, most differentially regulated DNA-binding genes in $\triangle$ Moisw2 mutation and the background strain Ku80 are physically close to the MoISW2 palindromic DNA binding motif site. The X-axis is the plus-minus gene distance from the gene closest to the MolSW2 binding site. Also, note that there is a pattern in their regulation at different distances from the binding sites. There are 4 peaks at -300 to $200,-70$ to $-30,30$ to 100 , and 240 to 400 . The dotted line shows 3 points moving average to highlight this. 


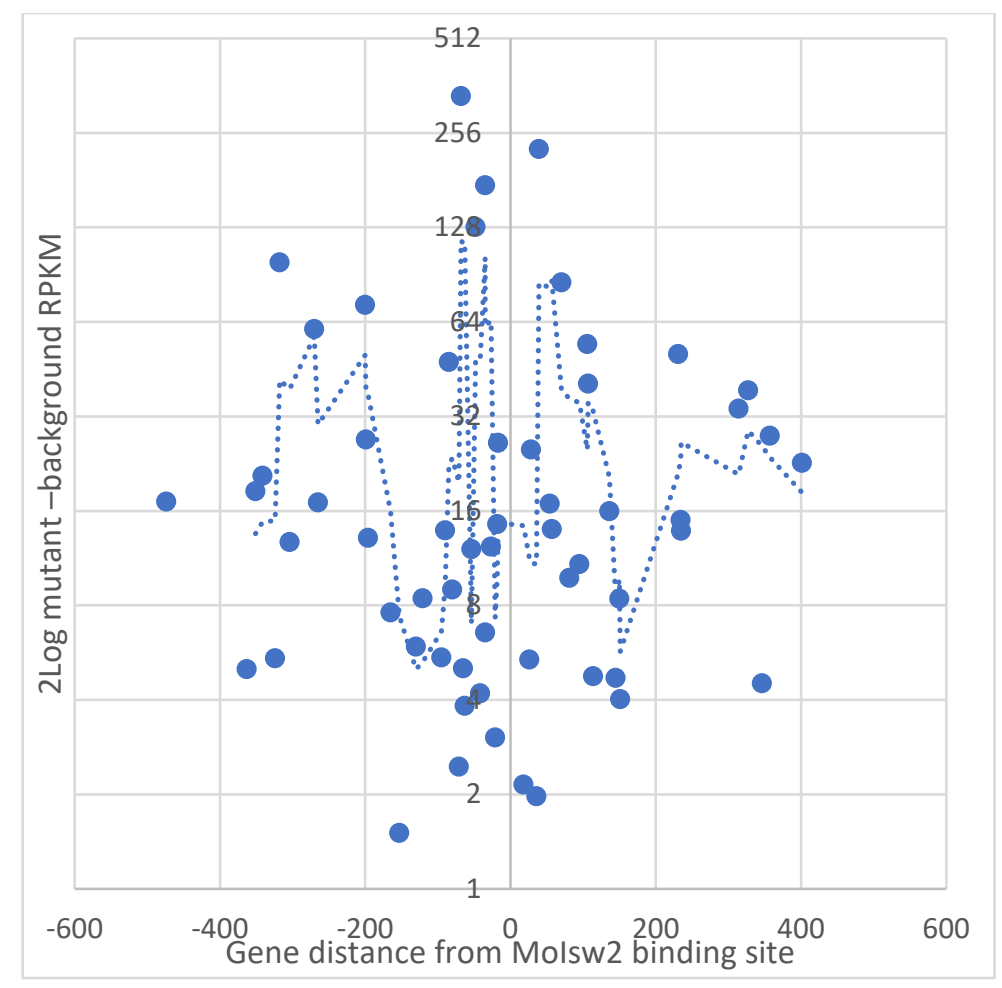

Figure S3. Same as Fig. 6 but with 2Log Y-axis to better show that the expression of the DNA binding genes around the Molsw2 DNA binding site has changed with the DMoisw2 mutation. There are in principle 4 peaks at -300 to $200,-70$ to 30,30 to 100 , and 240 to 400 . The dotted line shows 3 points moving average to highlight this.

Table 2. Genes close to the Molsw2 binding motif and most upregulated in $\Delta$ Moisw2 compared to the background Ku80-strain with annotation from NCBI

\begin{tabular}{|l|l|}
\hline MGG_02762 & MGG_02762. ATP-dependent RNA helicase DED1; Belongs to the DEAD box helicase family \\
\hline MGG_06470 & MGG_06470, DNA repair helicase RAD25 (835 aa). \\
\hline MGG_05948 & $\begin{array}{l}\text { MGG_05948 zinc knuckle domain-containing protein. This domain is a zinc-binding domain } \\
\text { of the form CxxCxxxGHxxxxC from various species. It is found in the MPE1 protein from } \\
\text { Saccharomyces cerevisiae which is a component of the cleavage and polyadenylation factor } \\
\text { (CPF) complex important for polyadenylation-dependent pre-mRNA 3'-end formation }\end{array}$ \\
\hline MGG_01990 & b-ZIP transcription factor IDI-4 (induces autophagic cell death in Podospora) \\
\hline MGG_02429 & $\begin{array}{l}\text { KOG4062 6-O-methylguanine-DNA methyltransferase MGMT/MGT1, involved in DNA repair } \\
\text { Replication, recombination and repair https://jgi-myco-web- } \\
\text { 4.jgi.doe.gov/annotator/servlet/jgi.annotation.Annotation?pDb=Lasov1\&pStateVar=View\&p } \\
\text { Proteinld=680852\&pViewType=protein }\end{array}$ \\
\hline MGG_04428 & Zinc finger transcription factor ace1 \\
\hline MGG_05995 & $\begin{array}{l}\text { MGG_05995, Magnaporthe oryzae 70-15 hypothetical protein (244 aa), translin family } \\
\text { protein, Translin family (PF01997). If Translin here is a review about that } \\
\text { https://link.springer.com/article/10.1007/s12038-019-9947-6 }\end{array}$ \\
\hline MGG_04429 & $\begin{array}{l}\text { ATP-dependent DNA helicase MPH1; ATP-dependent DNA helicase is involved in DNA } \\
\text { damage repair by homologous recombination and genome maintenance. }\end{array}$ \\
\hline
\end{tabular}

Of the DNA-binding genes most suppressed by Molsw2 activity and closest to the MoISW2 binding site, only two encode conventional TFs; the others are mainly involved in DNA repair (Table 2) needed for DNA synthesis and growth.

To get further information about the genes Molsw2 nucleosome interactions directly can regulate, we investigated which genes were situated $+8 /-8$ genes from the MolSW2 binding sites 
bioRxiv preprint doi: https://doi. org/10.1101/2022.02 27.481874 this version posted March 1.2022. The copyright holder for this preprint (which was not certified by peer review) is the author/funder, who has granted bioRxiv a license to display the preprint in perpetuity. It is made available under aCC-BY-NC-ND 4.0 International license.

(Supplemental Data S4) in the M. oryzae genome using FunCat classification. In the background possessing Molsw2, these genes are more likely to be regulated (positive or negative). These genes can be expected to be most influenced by Molsw2 chromatin-modifying activities. Interestingly, significantly enriched genes that are physically close to the Molsw2 binding sites are gene categories indicative of interaction with the abiotic and biotic environment, while significantly depleted genes are related to DNA synthesis and growth. The depleted genes are, in principle, indicative of housekeeping. Thus, combined with the above, it appears that MoISW2 is a switch between growth and interaction with the environment.

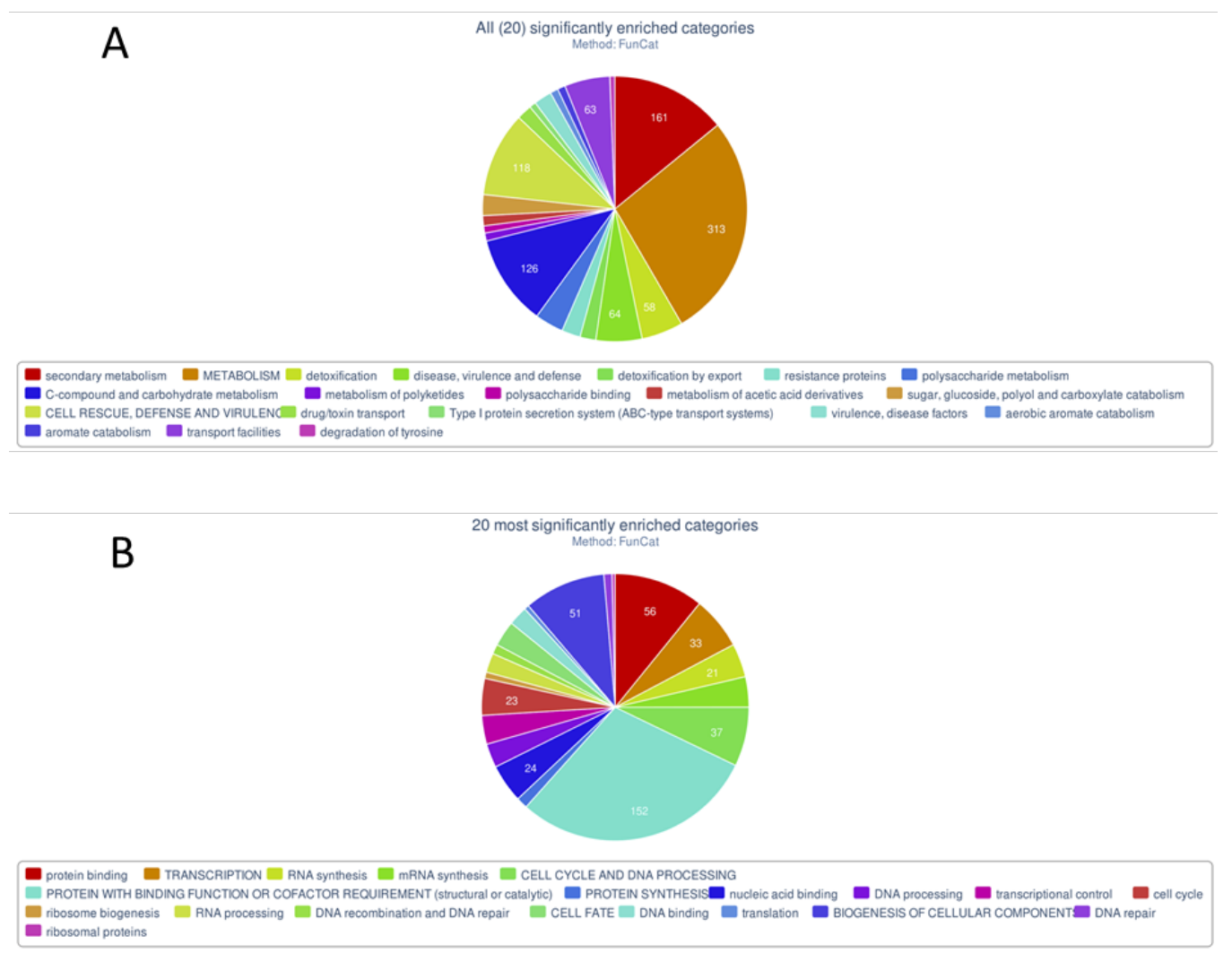

Figure 7. Significantly enriched categories $(\mathbf{A})$ are abiotic and biotic interaction-related categories for the genes closest ( $8+/-8$ genes) to the Molsw2 binding site. Significantly depleted categories (B) are growth-related protein and DNA synthesis-related genes.

\section{Molsw2 is likely involved in the regulation of core secondary metabolism genes}

Interactions with the environment (biotic and abiotic) and secondary metabolism are two categories that, together with the regulation of avirulence genes and closeness to transposons, could indicate that MoISW2 is instrumental in creating Non-Conserved Regions (NCRs) in M. oryzae. These gene categories positioning in NCRs have been characterized in Fusarium. graminearum compared to conserved regions containing housekeeping genes (Zhao et al., 2014). To investigate the positioning of secondary metabolite genes, we used the Anti-SMASH website and searched the complete MoDNA sequence for core secondary metabolite genes, so we are not dependent on previous annotations from the literature. We found 54 core secondary metabolite genes (Supplemental Data 6). Of these genes, 19 are positioned $+8 /-8$ genes from the Molsw 2 binding sites, and 25 are within 
bioRxiv preprint doi: https://doi org/10.1101/2022 02 27.481874. this version posted March 1, 2022. The copyright holder for this preprint (which was not certified by peer review) is the author/funder, who has granted bioRxiv a license to display the preprint in perpetuity. It is made available under aCC-BY-NC-ND 4.0 International license.

the double-distance from the binding site. Using the Fisher exact test (Table S1) and testing against random distribution, the P-value for the null hypothesis that the distribution is random is $2.18 \mathrm{E}-08$ for the 19 genes closest to the Molsw2 binding site and 1.93E-08 for the double gene distance from the binding site. In other words, there is a highly significant overrepresentation of secondary metabolite genes close to the Molsw2 palindromic DNA binding motif site. Most of the 19 closest genes are also differentially regulated by Molsw2, indicating that Molsw2 seems to regulate their expression (Fig. 8) actively.

Table S1 Input for Fisher's Exact

\begin{tabular}{|c|c|c|c|c|}
\hline & \multicolumn{2}{|c|}{$\begin{array}{l}+8 /-8 \text { genes from MolSW2 } \\
\text { DNA binding }\end{array}$} & \multicolumn{2}{|c|}{$\begin{array}{l}\text { Double gene distance Molsw2 } \\
\text { DNA binding }\end{array}$} \\
\hline & Total & Sec met genes & Total & Sec met genes \\
\hline $\begin{array}{l}\text { In } \\
\text { selection }\end{array}$ & 951 & 19 & 1902 & 25 \\
\hline $\begin{array}{l}\text { Not in } \\
\text { selection }\end{array}$ & 12233 & 35 & 11282 & 29 \\
\hline
\end{tabular}

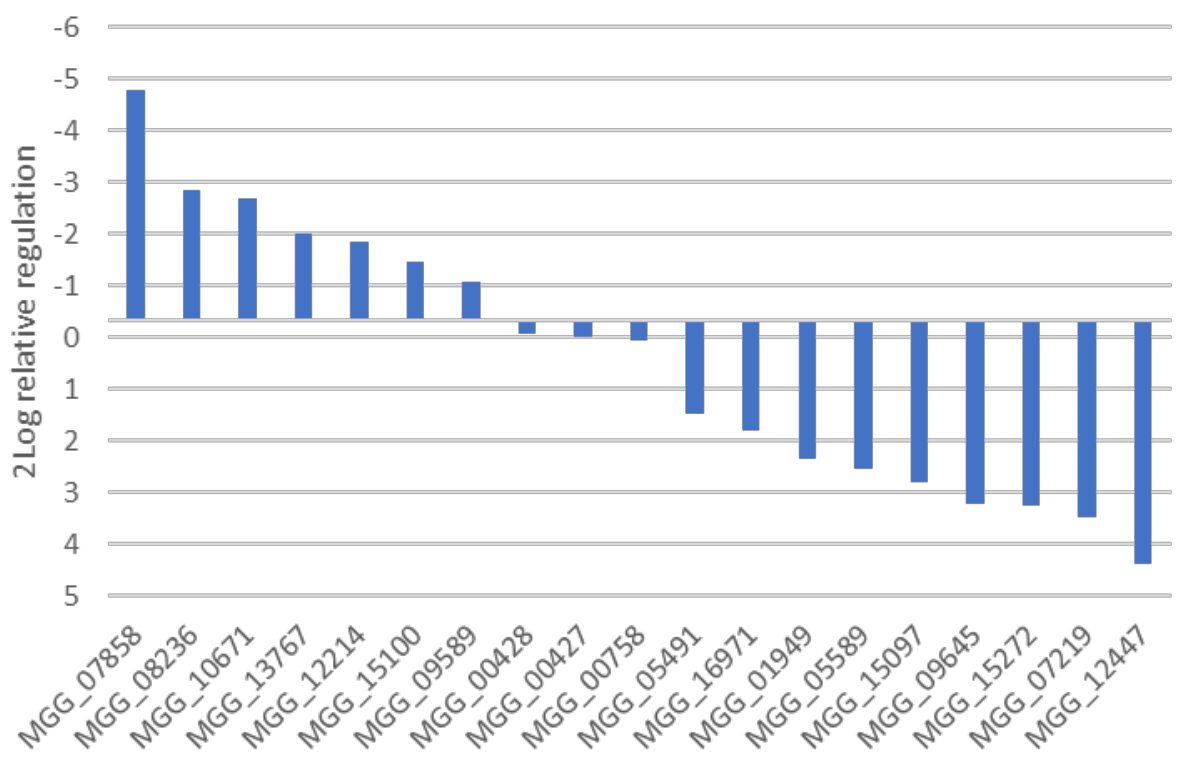

Figure 8. Core secondary metabolite genes according to an AntiSmash search of the whole genome (Supplementary data 2, (magnaporthe_oryzae_70-15_8_genes.zip) file containing the search output as a Zipped website unzip to a new folder to a new folder and run the index-file). Negative values show upregulation in the Ku80 background (regulated by Molsw2) compared to $\Delta$ Moisw2, while positive values show downregulation in Ku80 compared to $\Delta$ Moisw2.

Molsw2 binding to DNA sequences close to or inside genes 
bioRxiv preprint doi: https//doi org/10.1101/2022.02 27.481874· this version posted March 1 2022. The copyright holder for this preprint (which was not certified by peer review) is the author/funder, who has granted bioRxiv a license to display the preprint in perpetuity. It is made available under aCC-BY-NC-ND 4.0 International license.

We now turn back to the rest of the ChIP-seq data. We have above shown that genes under MoISW2 control that are more expressed in the background Ku80 strain compared to the $\Delta M o i s w 2$ strain are enriched for gene classes characteristic for secondary metabolism and biomass growth (anabolism) (Fig. 5A), while the downregulated genes in the mutant are genes connected to aerobic metabolism and stress (Fig. 5A).

In the Molsw2 ChIP-seq data, we investigated the FunCat classification of all genes with hits. First, we removed double hits not to count the same gene twice. We then investigated the list of genes closest to the Molsw2 palindromic DNA binding motif site. These genes should be targeted by Molsw2 and might be under positive or negative control from Molsw2. According to the previous analysis, they should not belong to growth (anabolism) but be genes active when oxygen is consumed and the substrates oxidized (catabolism) (Klevecz et al., 2004; Machné and Murray, 2012). In addition, the binding is in sequences close to avirulence genes and retrotransposons, so their regulation can shift depending on retrotransposon transpositions. Since ChIP-seq only shows potential binding to DNA in vivo, we cannot say if these genes are up or downregulated, only that regulation influenced by Molsw2 can occur. Genes hits close to the Molsw2 palindromic DNA binding motif site are mainly enriched for secondary metabolite genes and other gene classes essential for biotic interactions (Fig. 9A), while specific gene categories for biomass growth and housekeeping (anabolism) are depleted (Fig. 9B).
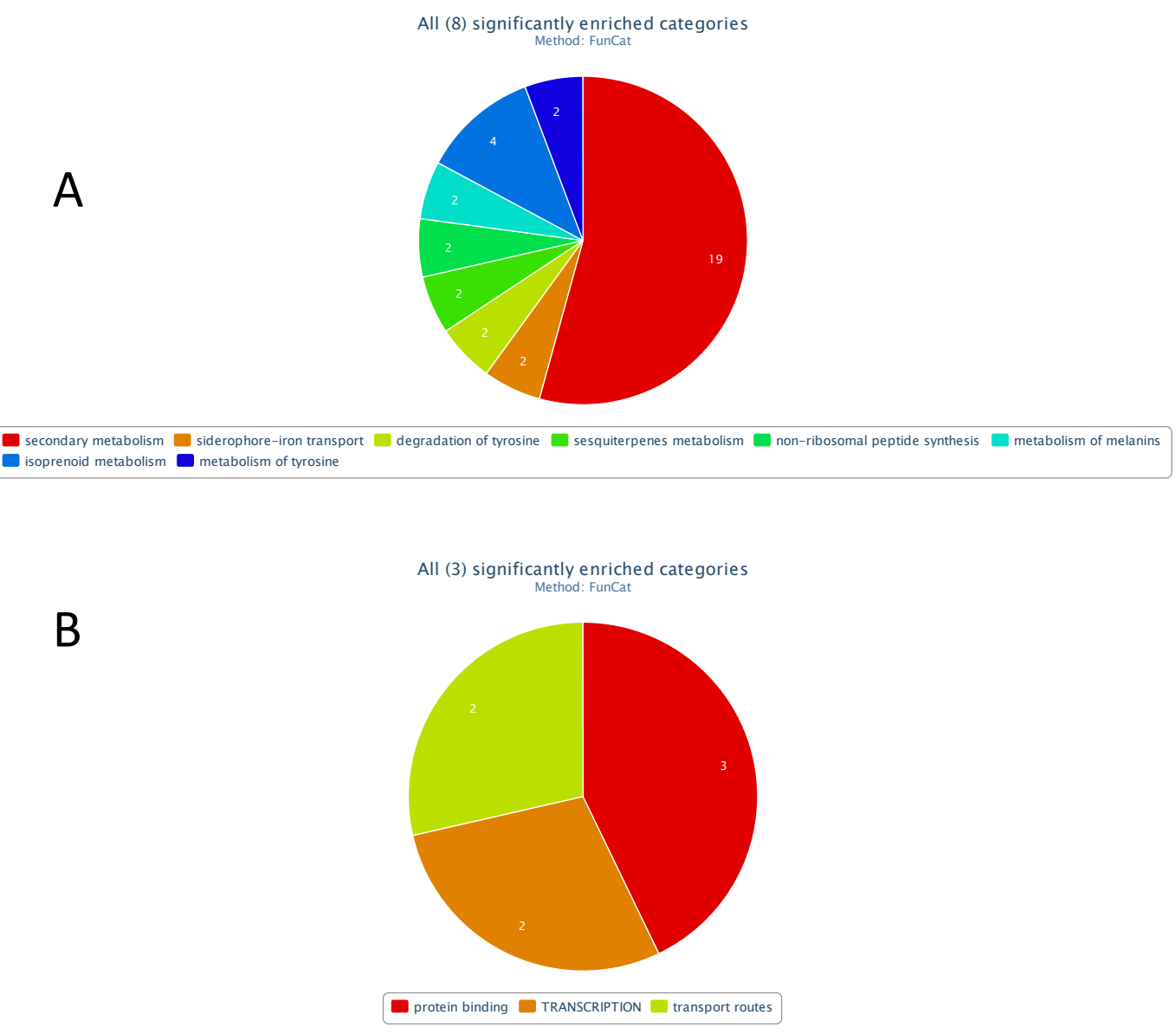

Figure 9. FunCat classification of genes closest to Molsw2 ChIP-seq binding that also has the Molsw2 binding palindromic motif. (A) Enriched classes of genes, and (B) depleted classes of genes. 
bioRxiv preprint doi: https:/doi.org/10.1101/2022 $02.27 .481874 \cdot$ this version posted March 1 2022. The copyright holder for this preprint (which was not certified by peer review) is the author/funder, who has granted bioRxiv a license to display the preprint in perpetuity. It is made available under aCC-BY-NC-ND 4.0 International license.

Genes with MolSW2 binding their promoter, or in their exons, or introns are other genes likely regulated by Molsw2 nucleosome positioning activity during anabolism/catabolism shifts. These genes are many more than those close to Molsw2 palindromic DNA motif sites, and we detect more gene classes (Fig. 10A), including detoxification, signaling (cyclic nucleotide-binding), disease, and defense as classes important in biotic and abiotic interactions with the environments. Depleted are again gene classes characteristic for anabolism (biomass growth) (Fig. 10B)

$10 \mathrm{~A}$ Enriched 20 most significantly enriched categories
Method: FunCat

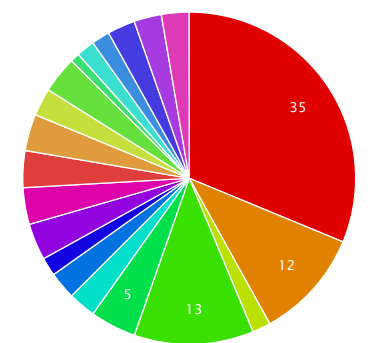

secondary metabolism detoxification cyclic nucleotide binding (cAMP, cGMP, etc.)

non-ribosomal peptide synthesis regulation of apoptosis aromate metabolism metabolism of acetic acid derivatives amino acid/amino acid derivatives transport $\mathbf{\text { serine/threonine kinas }}$ metabolism of polyketides metabolism of secondary products derived from primary amino acids induction of apoptosis by extracellular signals rhythm (e.g. circadian, ultradian)

regulation of directional cell growth $\square$ allantoin and allantoate transport $\square$ aerobic aromate catabolism osmosensing and response

Figure 9. FunCat classification of genes closest to Molsw2 ChIP-seq binding that also has the Molsw2 binding palindromic motif. (A) Enriched classes of genes, and (B) depleted classes of genes. 
bioRxiv preprint doi: https:/doi.org/10.1101/2022 $02.27 .481874 \cdot$ this version posted March 1.2022 . The copyright holder for this preprint (which was not certified by peer review) is the author/funder, who has granted bioRxiv a license to display the preprint in perpetuity. It is made available under aCC-BY-NC-ND 4.0 International license.

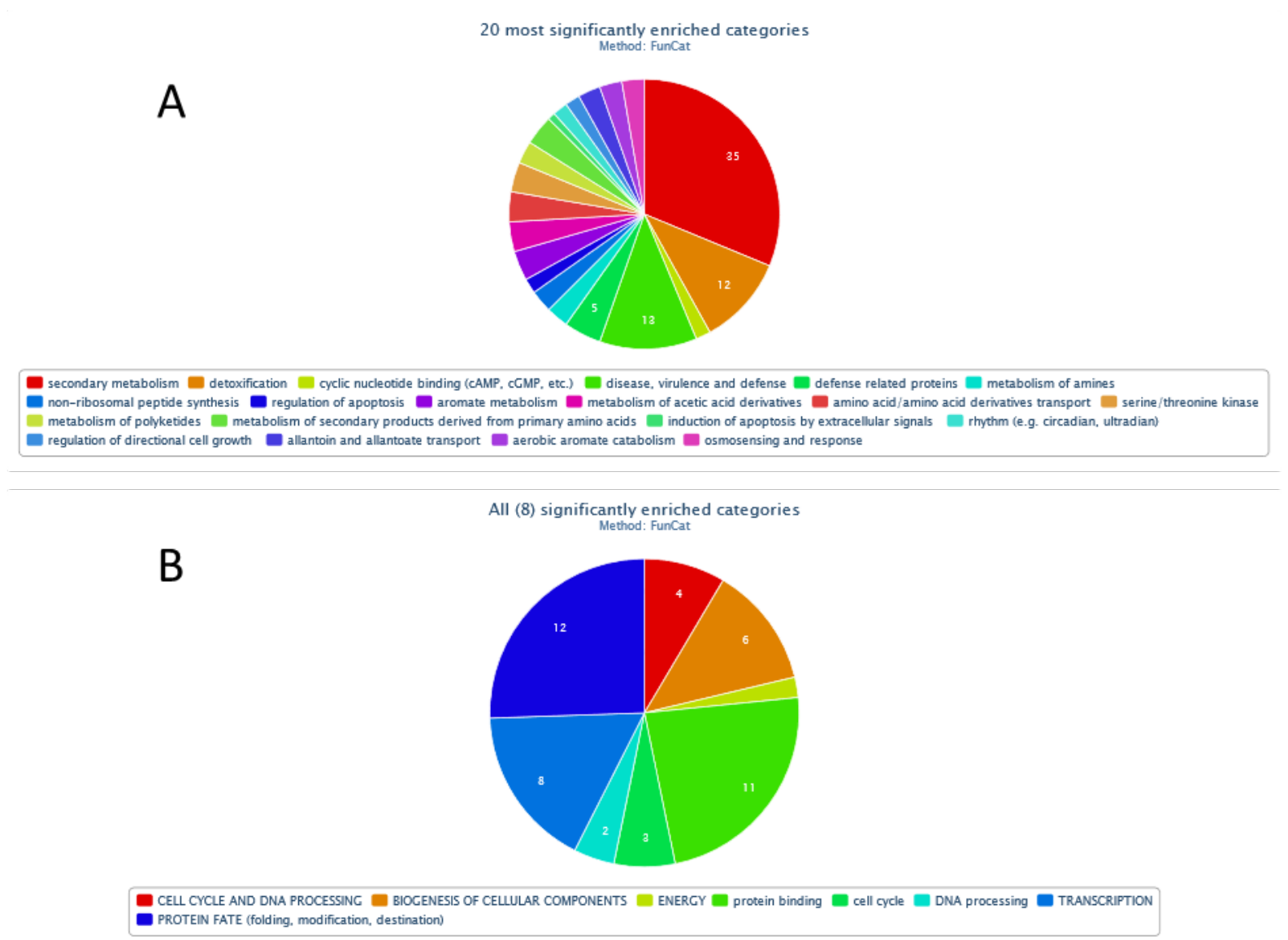

Figure 10. FunCat classifications of genes with ChIP-seq Molsw2 binding to their DNA sequences (excluding the palindromic motif hits in Fig. 9). (A) Enriched classes of genes and (B) depleted classes of genes.

Finally, as shown in Fig. 11, genes closest to ChIP-seq hits in intergenic regions, not containing the Molsw2 palindromic DNA binding motif site, are again genes enriched for secondary metabolite genes and genes involved in abiotic and biotic interactions (Fig. 11A). In contrast, genes needed for biomass growth are again depleted (Fig. 11B). 
bioRxiv preprint doi: https:/doi org/10.1101/2022.02 27.481874 this version posted March 1 2022. The copyright holder for this preprint (which was not certified by peer review) is the author/funder, who has granted bioRxiv a license to display the preprint in perpetuity. It is made available under aCC-BY-NC-ND 4.0 International license.

A

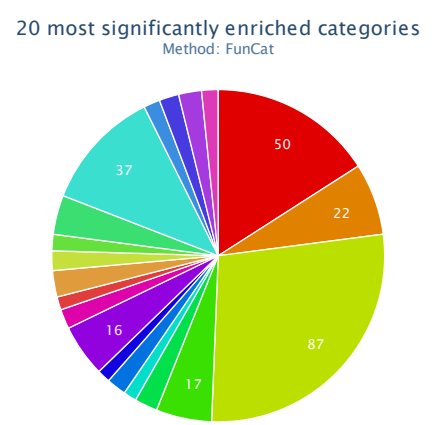

secondary metabolism disease, virulence and defense METABOLISM detoxification defense related proteins $\square$ amine / polyamine transport detoxification involving cytochrome P450 metabolism of amines complex cofactor/cosubstrate/vitamine binding metabolism of secondary products derived from primary amino acids metabolism of polyketides resistance proteins glycolysis and gluconeogenesis metabolism of acetic acid derivatives polysaccharide metabolism C-compound and carbohydrate metabolism amino acid/amino acid derivatives transport detoxification by export drug/toxin transport heme binding

\section{B}

20 most significantly enriched categories

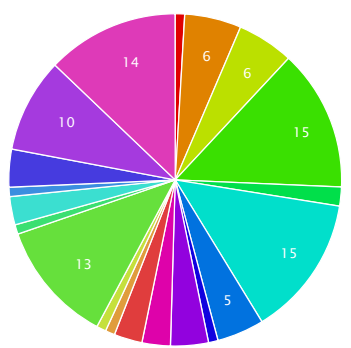

RNA synthesis TRANSCRIPTION CELL CYCLE AND DNA PROCESSING protein binding DNA processing PROTEIN FATE (folding, modification, destination)

nucleotide/nucleoside/nucleobase metabolism stress response REGULATION OF METABOLISM AND PROTEIN FUNCTION protein targeting, sorting and translocation RNA binding BIOGENESIS OF CELLULAR COMPONENTS DNA restriction or modification PROTEIN SYNTHESIS DNA conformation modification (e.g. chromatin) mitotic cell cycle and cell cycle control protein modification transport routes

Figure 11. FunCat classifications of genes closest to intergenic hits (excluding the palindromic motif hits) for Molsw2 binding. (A) Enriched classes of genes and (B) depleted classes of genes

\section{Discussion}

The yeast Isw 1 and Isw 2 interactions with His4 are very transient (approximately 200 and 80 bindings per minute, respectively) and need a continuous ATP supply (Tsukiyama et al., 1999). Thus our attempts to detect Molsw2 interaction with MoHis4 using the yeast twohybrid method were not likely to give positive results. Isw1 translocate nucleosomes away from other nucleosomes, while Isw2 does the same towards the center of DNA pieces and towards other nucleosomes in vitro, with the nucleosomes bound to relatively short DNA pieces (Kagalwala et al., 2004; Zofall et al., 2004). It does so also in vivo where it was found that Isw2 is mainly involved in targeted silencing of DNA around the ISW2 DNA binding site (Fazzio et al., 2005), as we also find (Fig. 3,6, Table 1). Taken together, this silencing of genes closest to the DNA-binding site should be very ATP-dependent and dependent on the competition for ATP in the cytoplasm and nucleus shared compartment of free diffusion for small molecules.

ATP generation from fermentation is much faster than from oxidative phosphorylation when glucose is available. In yeast, growth is also characterized by DNA replication, mainly without mitochondrial oxidative activity (aerobic glycolysis), most probably to protect DNA from mutations (Klevecz et al., 2004). In M. oryzae Molsw2 could thus be an ATP regulated switch (Machné and Murray, 2012) between fast aerobic glycolysis, 
DNA-synthesis growth and quality control, slower oxidative phosphorylation growth, oxidative defenses, and interaction with the abiotic and biotic environment that makes up the $M$. oryzae ecological niche. We found that genes upregulated in the $\Delta$ Moisw2 mutant are involved in fast growth and DNA-synthesis, and also genes necessary for DNA quality control while downregulated genes in the mutant were those involved in oxidative phosphorylation, stress management, and secondary metabolite biosynthesis (Fig. $\mathbf{5}$ and Table 2). As expected, the genes closest to the two central nucleosomes to the binding site should be downregulated in the background Ku80 (Donovan et al., 2021), and when Molsw2 is deleted, such genes should be upregulated. We could also note that downregulation in the background Ku8O depended on the distance from the ISW2 binding site (Fig. 2). Outside this central downregulation of DNA synthesis related genes and two TFs close to the ISW2 binding sites (Fig. 6), genes are expected to become more easily regulated since the ISW2 positioning of two nucleosomes close gives more sliding space of surrounding nucleosomes and thus the possibility for regulation (Donovan et al., 2021). The 16 genes closest to the predicted Molsw2 palindromic DNA binding motif sites are expected to be most affected by Molsw2 local nucleosome condensation. These are genes involved in responding to environmental cues (secondary metabolite production, oxidative stress response), further strengthening the general observation about genes regulated in the mutant (Fig. 2).

Our observations suggest that the $M$. oryzae genome is divided into genes needed for interaction with the environment similarly surrounded by house-keeping genes as described for the non-conserved regions in Fusarium graminearum where these types of genes are overrepresented (Zhao et al., 2014). One of the most potential DNA-binding sites for the MoISW2 is a palindromic motif giving instability to the genome at this site (Ganapathiraju et al., 2020; Svetec Miklenić and Svetec, 2021) and characteristic of motifs for retrotransposons situated close to stress-related genes and avirulence genes (plant pathogen effectors with a difference in resistance against by cultivars, thus the cause of avirulence against these cultivars)(Yoshida et al., 2016). The authors also found that a gene linkage to transposons is connected with elevated mutation rates. Different mutation rates or mutation bias of genes as a new concept have recently been described for the plant Arabidopsis thaliana (Monroe et al., 2022). Genes with higher mutation rates are involved in biotic and abiotic interactions, and the gene found with the highest mutation rate was a gene responding to chitin present in fungi and insects (Monroe et al., 2022). Our results show changes in the regulation of the avirulence genes between two $M$. oryzae strains with different pathogenicity to different rice cultivars (Table 2). Also, we could not detect any expression for some putative avirulence genes close to the Molsw2 binding sites indicating that those genes are potential pseudogenes in these strains. That might indicate a retrotransposon-aided genetic evolution of inherited epigenetic changes to regulation in reactions to the environment (resistance of the plant cultivar). A regulation that can be genetically fixed, first through loss of possible regulation (making genes into gene copyies and or potential pseudogene), and much later complete gene loss or break-up of the potential pseudogenes so they cannot be easily recognized as genes.

Potential pseudogenes close to retrotransposons were also found for stress-induced retrotransposon activities resulting in a "biased" faster evolution (Chadha and Sharma, 2014). The loss of ISW2 function in a unicellular Eukaryote or the early stages of fungal growth from a spore should make it unfit for survival in a natural environment. Our results indicate that MoISW2 regulates a switch between fast glycolytic growth and slower aerobic stress characterized growth, coping with abiotic and biotic stresses, or in other words, niche fitness. However, fast glycolytic growth could result in fast uncontrolled cell 
growth in a long-lived multicellular organism since ATP and glucose can be received from surrounding cells and other tissues through the blood circulation.

Mutations of the genes SMARKA2 or SMARKA4 that encode BRM and BRG1 proteins that are orthologues of fungal Swi2/Snf2 involved in nucleosome positioning in a way that has similarities to the nucleosome movements Isw2 cause (Reisman et al., 2009; Mittal and Roberts, 2020). In many cancer types, SMARKA2 or SMARKA4 are mutated (Reisman et al., 2009; Hasan and Ahuja, 2019; Mittal and Roberts, 2020). The human gene encoding an orthologue protein to Molsw2 is SMARCA1, and mutations in this gene can cause some cancers (Ye et al., 2009). However, a knockdown of SMARCA1s activities in breast cancer cell lines causes increased apoptosis-independent DNA damage, killing cancer cells, although not all breast cancer lines are dependent on its expression for survival (Ye et al., 2009).

A general shift to aerobic glycolysis and fast upregulation (within a few hours) of innate immunity-related genes associated with tissue inflammation is characteristic of fast defense against microbes through fast iron uptake, antimicrobial peptide production, and other responses needing rapid translational responses, as shown for Fusarium graminearum is general for eukaryotes (Ipcho et al., 2016). Such fast upregulated innate immune response in plants can be inhibited by fungal immune inhibitors acting on translation like trichothecenes the same fungus produce (Toyotome and Kamei, 2021), most likely to attenuate immune responses in the plants it infects. In consequence with this scenario, genes involved in RNA synthesis and RNA processing were upregulated in the $\Delta$ Moisw2 mutant (Fig. 5A), although the protein synthesis machinery is part of the general housekeeping and is further away from the Molsw2 DNA palindromic binding motif (Fig. 7). The latter point to a division of the $M$. oryzae genome into regions responsive to changes in the environment close to the Molsw2 palindromic DNA binding motif site and regions with mainly housekeeping genes between these binding sites in a way slightly similar to what is described for $F$. graminearum non-conserved regions and conserved regions (Zhao et al., 2014) and what is also found for mutation bias in A. thaliana (Monroe et al., 2022). The high-mutation probability genes found in $A$. thaliana were mainly genes necessary for recognizing and responding to abiotic and biotic challenges (Monroe et al., 2022). The latter indicates that evolution to better fit the niche (evolution of new species and strains) proceeds faster than random mutation in the whole genome alone, followed by selection (Monroe et al., 2022).

MolSW2 is possibly taking part in a mechanism aiding both mutation bias and adaptation to new circumstances whose combined activities lead to natural adaptation-directed fast evolution (NADFE), a bit similar to artificial adaptation-directed fast evolution that can be performed in a laboratory (Packer and Liu, 2015). Since transposon Molsw2 palindromic DNA binding seems necessary for binding to these palindromic sites, stress-activated transposon activity known for creating genomic instability can then, together with the Molsw2 activity, create a new adaptive regulatory landscape (Chadha and Sharma, 2014) that can be stabilized relatively quickly and lead to a sort of mutation bias (Monroe et al., 2022). It also would, in addition, be one mechanism sought after for a Lamarckian-Darwinian synthesis to help explain the fast evolution of new traits requiring many combined mutations that cannot be reconciled within Darwinian evolution based only on random mutations creating variation and sexual recombination with natural selection favoring the better fitted (Bard, 2011). The chance of multiple mutations that together can become positive is theoretically much more likely with NADFE aided by mutation bias (Monroe et al., 2022). ISW2 
activities in eukaryotes could thus be one of the needed mechanisms to reconcile Lamarckian evolution with Darwinian evolution to bring about both the observed direction and the needed speed of evolution of specific traits when new niches become available or there are drastic niche changes (Bard, 2011).

As a consequence of the present research, the effect of exposing $M$. oryzae strains to different Molsw2 activities and retrotransposon activities on the rate of genetic adaptation to a shift in rice cultivar is a possible future topic that could be exploited to understand how the pathogen adapts to different resistant cultivar and break plant resistance. Searching for potential agrochemicals to manipulate MolSW2 activities is tempting since MolSW2 is crucial for plant pathogenicity, although Molsw2's close resemblance to mammalian proteins with the same function indicates that such chemicals are likely affecting mammals and might be cancerogenic to humans. Finally, we found 2 MoHIS4 genes predicted to encode for identical proteins but differently regulated (Fig. 1), and it seems like $M$. oryzae needs both genes. This fact is of interest since His4 in the nucleosomes is what Molsw2 is supposed to interact with (Tsukiyama et al., 1999). We have thus started new research into the roles and regulation of these two MoHIS4 genes and how their regulations shift with growth conditions. Their predicted identical amino acid sequences indicate they are evolutionarily constrained to vary only by synonymous mutations.

\section{Materials and Methods}

\section{Fungal strains and media}

Magnaporthe oryzae (B. Couch) anamorph of the teleomorph Pyricularia oryzae (Cavara) was the fungus used. The MoISW2-GFP complement strain derived from the $\triangle M o i s w 2$ strain in the background strain Ku80 has previously been described (Li et al., 2021). For both ChIP-seq and RNAseq, the strains used were grown and harvested in the same way. For ChIP-seq MoISW2-GFP and Ku80 were used, and for RNAseq $\triangle M$ Moisw2 and Ku80 were used. The strains were grown on CM2 solid medium.

Complete medium 2 (CM2) all quantities $\mathrm{L}^{-1}: 20 X$ Mineral salts solution $50 \mathrm{~mL}, 1000 X$ Trace element solution $1 \mathrm{~mL}, 1000 X$ vitamin solution $1 \mathrm{~mL}$, D-glucose $10 \mathrm{~g}$, peptone $2 \mathrm{~g}$, casamino acid $1 \mathrm{~g}$, yeast extract $1 \mathrm{~g}, \mathrm{pH}$ 6.5. For agar medium add 15g agar.

20×Mineral salts solution(1000mL): $\mathrm{NaNO} 3120 \mathrm{~g}, \quad \mathrm{KCl} 10.4 \mathrm{~g}, \quad \mathrm{MgSO} 47 \mathrm{H} 2 \mathrm{O} 10.4 \mathrm{~g}, \quad \mathrm{KH} 2 \mathrm{PO} 430.4 \mathrm{~g}$

1000X Vitamin solution (100mL) Biotin 0.01g, Pyridoxin 0.01g, Thiamine 0.01g, Riboflavin 0.01g, PABA ( $p$-aminobenzoic acid) $0.01 \mathrm{~g}$, Nicotinic acid $0.01 \mathrm{~g}$.

1000X Trace element (100mL): $\mathrm{ZnSO}_{4} 7 \mathrm{H}_{2} \mathrm{O} 2.2 \mathrm{~g}_{,} \mathrm{H}_{3} \mathrm{BO}_{3} 1.1 \mathrm{~g} \mathrm{MnCl}_{2} 4 \mathrm{H}_{2} \mathrm{O} 0.5 \mathrm{~g}, \mathrm{FeSO}_{4} 7 \mathrm{H}_{2} \mathrm{O} 0.5 \mathrm{~g} \mathrm{CoCl}_{2}$ $6 \mathrm{H}_{2} \mathrm{O} 0.17 \mathrm{~g}, \mathrm{CuSO}_{4} 5 \mathrm{H}_{2} \mathrm{O}, \mathrm{Na}_{2} \mathrm{MoO}_{4} 5 \mathrm{H}_{2} \mathrm{O} 0.15 \mathrm{~g}$, EDTA 4Na $5 \mathrm{~g}$.

The plates were incubated $4-5$ days at $28^{\circ} \mathrm{C}$ with alternating light-dark cycles (12/12). Mycelial disks (15-20) were punched out using a cork puncher at the colony's edge. The disks were then transferred to $100 \mathrm{ml} \mathrm{CM2}$ liquid medium and cultured for another 48h with shaking (160 RPM, Constant temperature culture oscillator, ZHWY-2102C, Shanghai Zhicheng Analytical Instrument 
Manufacturing Co., Ltd.). The obtained biomass was filtered using Miracloth, frozen in liquid nitrogen, and sent to the company on dry ice.

ChIP-seq and RNA-seq as well as RNA-seq.

Both these techniques were carried out by the company Wuhan IGENEBOOK Biotechnology Co.,Ltd, China, according to their method descriptions (Supplemental Company Methods file). The last steps about finding motifs and finding enriched gene classes were carried out differently and these steps not used are marked in the two method files.

\section{Additional software and add-ins}

Addins for MS Excel. The Fisher Exact add-in for MS Excel was downloaded from http://www.obertfamily.com/software/fisherexact.html. Excel solver is usually part of the MS Excel but must be activated in settings.

Freeware: We used the freeware PAST (Hammer et al., 2001) version 4.08 (released November 2021) for Reduced Major Axis (RMA) regression analysis to handle errors in both the $x$ and $y$ variables. A simple to use but powerful freeware program is available from the University of Oslo, Natural History Museum https://www.nhm.uio.no/english/research/infrastructure/past/. For simplicity, the data was handled and entered in MS Excel and then copy-pasted into PAST for analysis. The resulting plots were exported from PAST as SVG ector graphic files to be later translated into other vector graphic file formats.

\section{Websites used for analyses and getting necessary additional data}

NCBI: https://www.ncbi.nlm.nih.gov/ (sequence downloads, blasts, annotations including domain annotations)

BROAD: ftp://ftp.broadinstitute.org (download of gene order on supercontigs for the 70-15 strain, 1000 upstream DNA sequences for use in MEME)

MEME: https://meme-suite.org/meme/ (use of MEME and FIMO). (Bailey et al., 2015).

See the supplemental file for MEME settings and complete results (Supplemental Data 2). MEME motif 2 was the one with the most hits and was investigated in detail. This motif2 was used for TOMTOM by using the direct link to TOMTOM using the link from the MEME result, for results see the supplemental file (Supplemental Data 3).

FungiFun2 https://elbe.hki-jena.de/fungifun/fungifun.php (Priebe et al., 2015)

Species: Magnaporthe grisea 70-15 (synonym for M. oryzae 70-15).

Classification ontology: FunCat (contains relevant categories for plant pathogens)

Input IDs: For M. oryzae 70-15 the MGG_codes has to be used.

Advanced settings used: Significance level; 0.05. Significance test; Fisher's exact test. Test for; Enrichment or Depletion. Adjustment method; No adjustment. Annotation type, Select also indirectly annotated categories. 
These settings using No adjustment were used since the purpose was not to get super reliable enriched or depleted categories but to compare several FungiFun runs with different Gene ID sets.

\section{antiSMASH}

The complete DNA sequence was downloaded from BROAD. That was then submitted to antiSMASH (Blin et al., 2021) fungal version https://fungismash.secondarymetabolites.org/\#!/start and run with default parameter settings to find the primary genes predicted to be involved in producing secondary metabolites.

\section{Acknowledgments}

Professor Daniel J. Ebbole, Texas A\&M University, USA, is thanked since he pointed us to the Supercontig sorted gene file for the strain 70-15 that could be downloaded from the BROAD institute. This file was necessary for the present work. The National Science Foundation China financially supported this research (NSFC31871914). 


\section{References}

Bailey, T.L., Johnson, J., Grant, C.E., Noble, W.S., 2015. The MEME Suite. Nucleic Acids Res 43, W39W49. https://doi.org/10.1093/nar/gkv416

Bard, J.B., 2011. The next evolutionary synthesis: from Lamarck and Darwin to genomic variation and systems biology. Cell Commun Signal 9, 30. https://doi.org/10.1186/1478-811X-9-30

Blin, K., Shaw, S., Kloosterman, A.M., Charlop-Powers, Z., van Wezel, G.P., Medema, M.H., Weber, T., 2021. antiSMASH 6.0: improving cluster detection and comparison capabilities. Nucleic Acids Research 49, W29-W35. https://doi.org/10.1093/nar/gkab335

Chadha, S., Sharma, M., 2014. Transposable Elements as Stress Adaptive Capacitors Induce Genomic Instability in Fungal Pathogen Magnaporthe oryzae. PLoS ONE 9, e94415. https://doi.org/10.1371/journal.pone.0094415

Cheetham, S.W., Faulkner, G.J., Dinger, M.E., 2020. Overcoming challenges and dogmas to understand the functions of pseudogenes. Nat Rev Genet 21, 191-201. https://doi.org/10.1038/s41576-019-0196-1

Chereji, R.V., Ramachandran, S., Bryson, T.D., Henikoff, S., 2018. Precise genome-wide mapping of single nucleosomes and linkers in vivo. Genome Biol 19, 19. https://doi.org/10.1186/s13059018-1398-0

Collemare, J., Pianfetti, M., Houlle, A., Morin, D., Camborde, L., Gagey, M., Barbisan, C., Fudal, I., Lebrun, M., Böhnert, H.U., 2008. Magnaporthe grisea avirulence gene ACE1 belongs to an infection-specific gene cluster involved in secondary metabolism. New Phytologist 179, 196208. https://doi.org/10.1111/j.1469-8137.2008.02459.x

Cutter, A.R., Hayes, J.J., 2015. A brief review of nucleosome structure. FEBS Letters 589, 2914-2922. https://doi.org/10.1016/j.febslet.2015.05.016

Dang, W., Sutphin, G.L., Dorsey, J.A., Otte, G.L., Cao, K., Perry, R.M., Wanat, J.J., Saviolaki, D., Murakami, C.J., Tsuchiyama, S., Robison, B., Gregory, B.D., Vermeulen, M., Shiekhattar, R., Johnson, F.B., Kennedy, B.K., Kaeberlein, M., Berger, S.L., 2014. Inactivation of Yeast Isw2 Chromatin Remodeling Enzyme Mimics Longevity Effect of Calorie Restriction via Induction of Genotoxic Stress Response. Cell Metabolism 19, 952-966. https://doi.org/10.1016/j.cmet.2014.04.004

Dioh, W., Tharreau, D., Notteghem, J.L., Orbach, M., Lebrun, M.-H., 2000. Mapping of Avirulence Genes in the Rice Blast Fungus, Magnaporthe grisea, with RFLP and RAPD Markers. MPMI 13, 217-227. https://doi.org/10.1094/MPMI.2000.13.2.217

Donovan, D.A., Crandall, J.G., Truong, V.N., Vaaler, A.L., Bailey, T.B., Dinwiddie, D., Banks, O.G., McKnight, L.E., McKnight, J.N., 2021. Basis of specificity for a conserved and promiscuous chromatin remodeling protein. eLife 10, e64061. https://doi.org/10.7554/eLife.64061

Fazzio, T.G., Gelbart, M.E., Tsukiyama, T., 2005. Two Distinct Mechanisms of Chromatin Interaction by the Isw2 Chromatin Remodeling Complex In Vivo. Mol Cell Biol 25, 9165-9174. https://doi.org/10.1128/MCB.25.21.9165-9174.2005

Ganapathiraju, M.K., Subramanian, S., Chaparala, S., Karunakaran, K.B., 2020. A reference catalog of DNA palindromes in the human genome and their variations in 1000 Genomes. Hum Genome Var 7, 40. https://doi.org/10.1038/s41439-020-00127-5

Hammer, O., Harper, D.A.T., Ryan, P.D., 2001. PAST: Paleontological Statistics Software Package for Education and Data Analysis 4, 9.

Hasan, N., Ahuja, N., 2019. The Emerging Roles of ATP-Dependent Chromatin Remodeling Complexes in Pancreatic Cancer. Cancers 11, 1859. https://doi.org/10.3390/cancers11121859

Hota, S.K., Bartholomew, B., 2011. Diversity of operation in ATP-dependent chromatin remodelers. Biochimica et Biophysica Acta (BBA) - Gene Regulatory Mechanisms 1809, 476-487. https://doi.org/10.1016/j.bbagrm.2011.05.007

Huang, L., Li, X., Dong, L., Wang, B., Pan, L., 2021. Profiling of chromatin accessibility identifies transcription factor binding sites across the genome of Aspergillus species. BMC Biol 19, 189. https://doi.org/10.1186/s12915-021-01114-0 
bioRxiv preprint doi: https//doi.org/10.1101/2022.02.27.481874 this version posted March 1, 2022. The copyright holder for this preprint (which was not certified by peer review) is the author/funder, who has granted bioRxiv a license to display the preprint in perpetuity. It is made available under aCC-BY-NC-ND 4.0 International license.

Ipcho, S., Sundelin, T., Erbs, G., Kistler, H.C., Newman, M.-A., Olsson, S., 2016. Fungal innate immunity induced by bacterial microbe-associated molecular patterns (MAMPs). G3 6, 1585-1595. https://doi.org/10.1534/g3.116.027987

Kagalwala, M.N., Glaus, B.J., Dang, W., Zofall, M., Bartholomew, B., 2004. Topography of the ISW2nucleosome complex: insights into nucleosome spacing and chromatin remodeling. EMBO J 23, 2092-2104. https://doi.org/10.1038/sj.emboj.7600220

Klevecz, R.R., Bolen, J., Forrest, G., Murray, D.B., 2004. A genomewide oscillation in transcription gates DNA replication and cell cycle. Proceedings of the National Academy of Sciences 101, 1200-1205. https://doi.org/10.1073/pnas.0306490101

Li, Y., Zheng, X., Pei, M., Chen, M., Zhang, S., Liang, C., Gao, L., Huang, P., Olsson, S., 2021. Identification and characterization of 19 predicted Myb-family DNA binding proteins in Magnaporthe oryzae concerning growth, conidiation, and pathogenicity (preprint). BioRxiv. https://doi.org/10.1101/2021.12.28.474317

Linheiro, R.S., Bergman, C.M., 2008. Testing the palindromic target site model for DNA transposon insertion using the Drosophila melanogaster P-element. Nucleic Acids Research 36, 61996208. https://doi.org/10.1093/nar/gkn563

Machné, R., Murray, D.B., 2012. The Yin and Yang of Yeast Transcription: Elements of a Global Feedback System between Metabolism and Chromatin. PLoS ONE 7, e37906. https://doi.org/10.1371/journal.pone.0037906

Mittal, P., Roberts, C.W.M., 2020. The SWI/SNF complex in cancer - biology, biomarkers and therapy. Nat Rev Clin Oncol 17, 435-448. https://doi.org/10.1038/s41571-020-0357-3

Monroe, J.G., Srikant, T., Carbonell-Bejerano, P., Becker, C., Lensink, M., Exposito-Alonso, M., Klein, M., Hildebrandt, J., Neumann, M., Kliebenstein, D., Weng, M.-L., Imbert, E., Ågren, J., Rutter, M.T., Fenster, C.B., Weigel, D., 2022. Mutation bias reflects natural selection in Arabidopsis thaliana. Nature 602, 101-105. https://doi.org/10.1038/s41586-021-04269-6

Packer, M.S., Liu, D.R., 2015. Methods for the directed evolution of proteins. Nat Rev Genet 16, 379394. https://doi.org/10.1038/nrg3927

Priebe, S., Kreisel, C., Horn, F., Guthke, R., Linde, J., 2015. FungiFun2: a comprehensive online resource for systematic analysis of gene lists from fungal species. Bioinformatics $31,445-$ 446. https://doi.org/10.1093/bioinformatics/btu627

Reisman, D., Glaros, S., Thompson, E.A., 2009. The SWI/SNF complex and cancer. Oncogene 28, 1653-1668. https://doi.org/10.1038/onc.2009.4

Serrano, L., Vazquez, B.N., Tischfield, J., 2013. Chromatin structure, pluripotency and differentiation. Exp Biol Med (Maywood) 238, 259-270. https://doi.org/10.1177/1535370213480718

Song, Z., Bakeer, W., Marshall, J.W., Yakasai, A.A., Khalid, R.M., Collemare, J., Skellam, E., Tharreau, D., Lebrun, M.-H., Lazarus, C.M., Bailey, A.M., Simpson, T.J., Cox, R.J., 2015. Heterologous expression of the avirulence gene ACE1 from the fungal rice pathogen Magnaporthe oryzae. Chem. Sci. 6, 4837-4845. https://doi.org/10.1039/C4SC03707C

Svetec Miklenić, M., Svetec, I.K., 2021. Palindromes in DNA-A Risk for Genome Stability and Implications in Cancer. IJMS 22, 2840. https://doi.org/10.3390/ijms22062840

Toyotome, T., Kamei, K., 2021. In Vitro Assay of Translation Inhibition by Trichothecenes Using a Commercially Available System. Toxins 13, 696. https://doi.org/10.3390/toxins 13100696

Tsukiyama, T., Palmer, J., Landel, C.C., Shiloach, J., Wu, C., 1999. Characterization of the Imitation Switch subfamily of ATP-dependent chromatin-remodeling factors in Saccharomyces cerevisiae. Genes \& Development 13, 686-697. https://doi.org/10.1101/gad.13.6.686

van Holde, KE, 1989. Chromatin, Springer Series in Molecular Biology. Springer New York, New York, NY. https://doi.org/10.1007/978-1-4612-3490-6

Whitehouse, I., Rando, O.J., Delrow, J., Tsukiyama, T., 2007. Chromatin remodelling at promoters suppresses antisense transcription. Nature 450, 1031-1035.

https://doi.org/10.1038/nature06391 
bioRxiv preprint doi: https://doi.org/10.1101/2022.02 27.481874. this version posted March 1 2022. The copyright holder for this preprint (which was not certified by peer review) is the author/funder, who has granted bioRxiv a license to display the preprint in perpetuity. It is made available under aCC-BY-NC-ND 4.0 International license.

Willcockson, M.A., Healton, S.E., Weiss, C.N., Bartholdy, B.A., Botbol, Y., Mishra, L.N., Sidhwani, D.S., Wilson, T.J., Pinto, H.B., Maron, M.I., Skalina, K.A., Toro, L.N., Zhao, J., Lee, C.-H., Hou, H., Yusufova, N., Meydan, C., Osunsade, A., David, Y., Cesarman, E., Melnick, A.M., Sidoli, S., Garcia, B.A., Edelmann, W., Macian, F., Skoultchi, A.I., 2021. H1 histones control the epigenetic landscape by local chromatin compaction. Nature 589, 293-298. https://doi.org/10.1038/s41586-020-3032-z

Ye, Y., Xiao, Y., Wang, W., Wang, Q., Yearsley, K., Wani, A.A., Yan, Q., Gao, J.-X., Shetuni, B.S., Barsky, S.H., 2009. Inhibition of Expression of the Chromatin Remodeling Gene, SNF2L, Selectively Leads to DNA Damage, Growth Inhibition, and Cancer Cell Death. Mol Cancer Res 7, 19841999. https://doi.org/10.1158/1541-7786.MCR-09-0119

Yoshida, K., Saunders, D.G.O., Mitsuoka, C., Natsume, S., Kosugi, S., Saitoh, H., Inoue, Y., Chuma, I., Tosa, Y., Cano, L.M., Kamoun, S., Terauchi, R., 2016. Host specialization of the blast fungus Magnaporthe oryzae is associated with dynamic gain and loss of genes linked to transposable elements. BMC Genomics 17, 370. https://doi.org/10.1186/s12864-016-2690-6

Zhang, L., Zhang, D., Liu, D., Li, Y., Li, H., Xie, Y., Wang, Z., Hansen, B.O., Olsson, S., 2019. Conserved Eukaryotic Kinase CK2 Chaperone Intrinsically Disordered Protein Interactions. Appl Environ Microbiol 86, e02191-19, /aem/86/2/AEM.02191-19.atom. https://doi.org/10.1128/AEM.02191-19

Zhao, C., Waalwijk, C., de Wit, P.J., Tang, D., van der Lee, T., 2014. Relocation of genes generates non-conserved chromosomal segments in Fusarium graminearumthat show distinct and coregulated gene expression patterns. BMC Genomics 15, 191. https://doi.org/10.1186/14712164-15-191

Zofall, M., Persinger, J., Bartholomew, B., 2004. Functional Role of Extranucleosomal DNA and the Entry Site of the Nucleosome in Chromatin Remodeling by ISW2. Mol Cell Biol 24, 1004710057. https://doi.org/10.1128/MCB.24.22.10047-10057.2004 